\title{
Tobacco industry consumer research on socially acceptable cigarettes
}

\section{P M Ling, S A Glantz}

Tobacco Control 2005;14:e3 (http://www.tobaccocontrol.com/cgi/content/full/14/5/e3). doi: 10.1136/tc.2005.011239

See end of article for authors' affiliations

......................

Correspondence to: Pamela M Ling, MD MPH, Box 1390, 530 Parnassus Avenue, Suite 366 University of California San Francisco, San

Francisco, CA 94143-

1390, USA; pling@

medicine.ucsf.edu

Received 21 January 2005 Accepted 19 May 2005
Objective: To describe tobacco industry consumer research to inform the development of more "socially acceptable" cigarette products since the 1970s.

Methods: Analysis of previously secret tobacco industry documents.

Results: 28 projects to develop more socially acceptable cigarettes were identified from Philip Morris, RJ Reynolds, British American Tobacco, and Lorillard tobacco companies. Consumer research and concept testing consistently demonstrated that many smokers feel strong social pressure not to smoke, and this pressure increased with exposure to smoking restrictions. Tobacco companies attempted to develop more socially acceptable cigarettes with less visible sidestream smoke or less odour. When presented in theory, these product concepts were very attractive to important segments of the smoking population. However, almost every product developed was unacceptable in actual product tests or test markets. Smokers reported the complete elimination of secondhand smoke was necessary to satisfy non-smokers. Smokers have also been generally unwilling to sacrifice their own smoking satisfaction for the benefit of others. Many smokers prefer smoke-free environments to cigarettes that produce less secondhand smoke.

Conclusions: Concerns about secondhand smoke and clean indoor air policies have a powerful effect on the social acceptability of smoking. Historically, the tobacco industry has been unable to counter these effects by developing more socially acceptable cigarettes. These data suggest that educating smokers about the health dangers of secondhand smoke and promoting clean indoor air policies has been difficult for the tobacco industry to counter with new products, and that every effort should be made to pursue these strategies.
C oncern about the dangers of secondhand smoke (SHS) - both among smokers and non-smokers-has been critically important to the tobacco industry for decades. ${ }^{1}$ The industry responded with efforts to undermine the science on the dangers of SHS, ${ }^{2-7}$ campaigns to fight clean indoor air policies, and efforts to portray those who wished to address secondhand smoke from a public health perspective as extremists. ${ }^{8-12}$ Tobacco companies also promoted "accommodation programs" as an alternative to clean air policies, which had some success in delaying clean indoor air legislation in some parts of the world. ${ }^{11}{ }^{13-15}$ At the same time, the tobacco industry launched major product development and marketing efforts to address smokers' and nonsmokers' concerns about SHS. One of the strategies to "solve" this problem was to develop more socially acceptable products that would mask or eliminate SHS

Since the 1970s, tobacco companies developed, tested, and marketed a myriad of cigarette products designed to increase the social acceptability of smoking. None of these "low odor", "low sidestream" or "good smelling" products held a significant market share in 2003. ${ }^{16}$ In the late 1990s, tobacco companies started to offer "potentially reduced exposure products" (PREPs) which claimed to offer benefits to the non-smoker as well as the smoker, such as Omni (which claimed fewer carcinogens in its mainstream and sidestream smoke) or Eclipse (which claims potentially reduced harm, less sidestream smoke, and no lingering odour)..$^{17}$ There has been much prior research on how "light" and "mild" cigarettes provided reassurance to smokers about the health risks of smoking. ${ }^{19-24}$ While the technological development and use of additives to create some of these products ${ }^{25}$ and some studies on the health effects of SHS and testing of low smoke products ${ }^{26}$ have been described, there has been little focus on the marketing of these products and the consumer research used to develop them. The consumer research on socially acceptable products provides important insights into smoking behaviour and how social pressures motivate smokers.

The tobacco industry documents reveal that substantial segments of the smoker population are very concerned about the social acceptability of smoking. These smokers also tend to be very supportive of smoking restrictions. Many smokers were very interested in the concept of a socially acceptable cigarette, such as a cigarette with no sidestream smoke, no odour, a pleasant aroma, or a product that improved breath/ clothing/household odours for smokers. However, tobacco companies failed to develop products that could actually deliver on the concept. Most smokers were unwilling to compromise "taste" for such a product, because the benefit (less sidestream smoke) offered was for someone else, not the smoker. In addition, smokers knew that cigarette smoke is so noxious to non-smokers that no less than a $100 \%$ reduction in sidestream smoke or odour was likely to yield a more acceptable product. With a few exceptions, ${ }^{27} 28$ these products failed in test markets. In the 1990s, tobacco companies started to bundle product benefits together; as of 2005, most of the cigarette products that claim to have "less smoke" offer both reduced harm for the smoker and less sidestream smoke to affect the non-smoker. This research underscores the importance of educating smokers and non-smokers about the dangers of SHS and promoting smoke-free policies.

Abbreviations: BAT, British American Tobacco; FDA, Food and Drug Administration; PREPs, potentially reduced exposure products; RJR, RJ Reynolds; SHS, secondhand smoke 


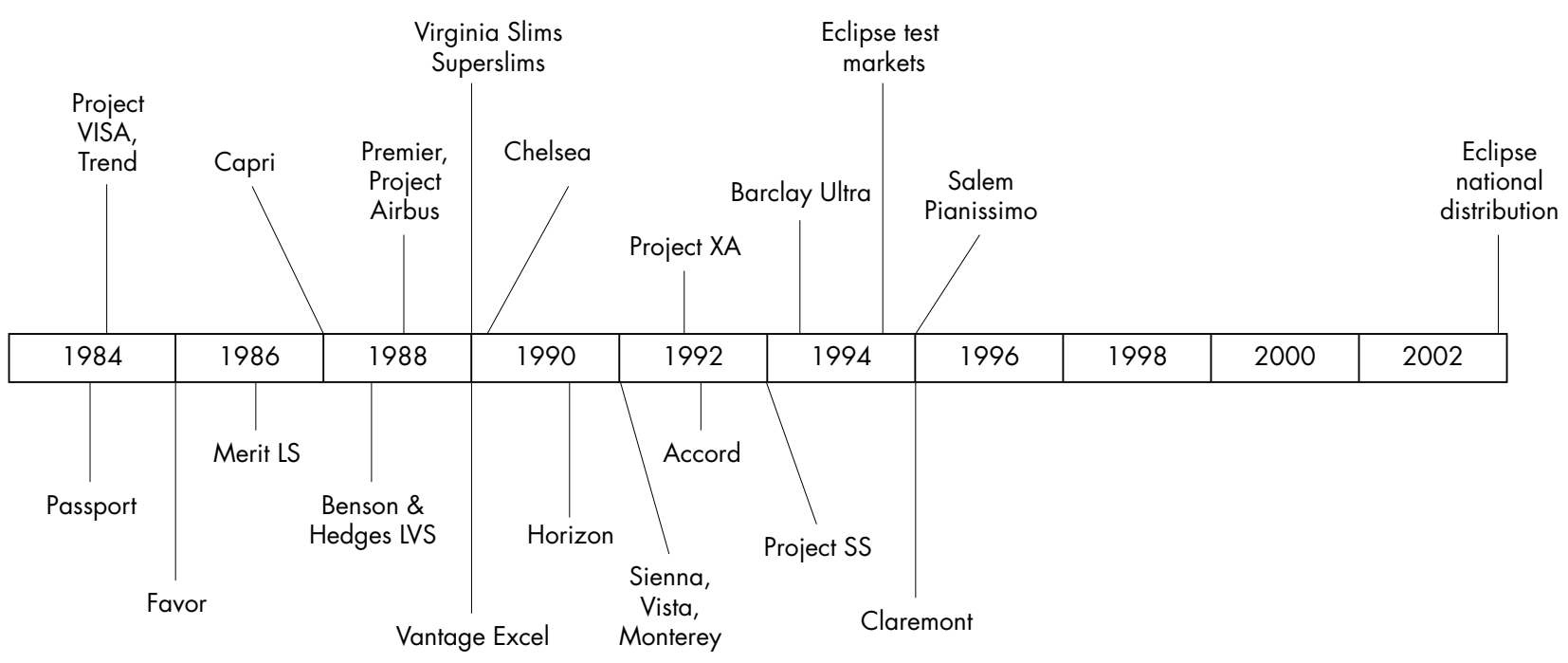

Figure 1 Timeline of introduction of potentially more socially acceptable cigarette products.

\section{METHODS}

We analysed tobacco industry documents focusing on the tobacco industry's attempt to "solve" the problem of social acceptability by developing new products. To address these issues, we collected marketing research on social acceptability, consumer concept testing of socially acceptable product concepts, consumer testing of prototype socially acceptable products, the history, success, or failure of these products in the marketplace, and strategic plans addressing social acceptability future strategies in this arena.

Initial searches were performed using tobacco industry document archives from the Legacy Tobacco Documents Library (legacy.library.ucsf.edu) and the British American Tobacco Documents Archive (bat.library.ucsf.edu) at the University of California, San Francisco. Tobacco industry documents internet sites (Phillip Morris, www.pmdocs.com; RJ Reynolds (RJR), www.rjrtdocs.com; Lorillard, www. lorillarddocs.com), Tobacco Documents Online (www. tobaccodocuments.org), and the Minnesota Select Set (outside.cdc.gov:8080/BASIS/ncctld/web/mnimages) were searched for supplemental information.

Searches were conducted between June 2003 and October 2004. Initial search terms were related to social acceptability, such as "social accept" $t^{*}$, "less smoke", "low sidestream", or "low odor", combined with search terms that identify research, such as "study", "research", or "marketing report". Initial searches yielded thousands of documents; documents containing consumer research related to more socially acceptable cigarette products were selected. Searches were repeated and focused using standard techniques. ${ }^{29}$ Further searches for contextual information on relevant documents were conducted using "snowball" searches on names, project titles, locations, dates, and reference (Bates) numbers. This analysis is based on a final collection of approximately 1225 research reports, presentations, memorandums, and plans. We sought to include any tobacco industry consumer research on socially acceptable cigarettes that tobacco companies proposed, funded, completed, or used to guide their marketing plans.

The consumer research and testing from all identified projects were collected and analysed to answer the following questions: (1) How does the social acceptability of smoking affect smoking behaviour? (2) What is the size of the market for "socially acceptable" products, and is it important? (3) What are the demographic and psychographic characteristics and motivations for smokers interested in more socially acceptable products? (4) What types of cigarette products and benefits have been developed, and which concepts are most attractive to smokers? (5) Which of these products been successful in the marketplace, and how does the tobacco industry account for its successes and failures?

Documents were analysed using repeated iterative reviews to construct coherent accounts of the marketing projects identified. Common principles, strategies, and themes that were replicated over several studies, and duplicated by several tobacco companies were identified and discussed by both authors. Questions were resolved by gathering additional data, and by triangulation with outside sources such as advertising archives, tobacco company websites, former employees, annual reports, news coverage, and trade press.

\section{RESULTS}

\section{Scope of documents analysed}

Tobacco companies recognised the importance of social acceptability in numerous countries worldwide, monitored the public perception of social acceptability in different countries, and pursued political and public relations strategies to combat growing unacceptability of smoking internationally, including "Operation Berkshire" and the Social Acceptability Working Party arm of the International Committee on Smoking Issues formed by international tobacco companies. ${ }^{30-34}$ However, this analysis focuses on consumer research and consumer testing of potentially more socially acceptable cigarette products, most of which was conducted in the USA or Canada. Unless otherwise stated, the research results we present were from US studies. We identified research on the social acceptability of smoking and its implications for new product development beginning in the 1970s, but most actual product testing with consumers was conducted after 1980. Figure 1 presents a time line of the introduction of different potentially more socially acceptable products identified in this study.

\section{How social acceptability affects smoking behaviour} Brown and Williamson has conducted research on the growing "socially concerned smoker segment" since at least $1976,{ }^{35}$ and recognised social concern as one of the "two key forces" driving brand switching in 1977.. ${ }^{36}$ Philip Morris reviewed the origins of decreasing social acceptability in a brief discussion paper written in 1977. ${ }^{37}$ RJR planned to develop a research programme on social acceptability in $1978,{ }^{38}$ and found that the decline in social acceptability of 
smoking was accelerating during the early 1980s. ${ }^{39} 40$ Consumer research on passive smoking was conducted for Lorillard in 1979, and the company considered developing a socially acceptable cigarette. ${ }^{41} 42$

A 1983 presentation by RJR director of new brands and strategic research summarised the importance of social acceptability to smokers:

\begin{abstract}
...we identified social interaction as one of the primary benefits people receive from smoking. Cigarettes are used by people to make themselves feel comfortable around others. They're used in those situations when smokers are trying to make friends, and as an aid in feeling more mature and attractive to others. Thus, as social acceptability declines, it threatens this primary benefit of smoking. ${ }^{43}$
\end{abstract}

Philip Morris researchers also recognised the eroding social acceptability of smoking in the 1980s; according to a report the manager of business development and consumer research, Jan Jones, prepared for Dr Ed Gee, director of consumer research:

In the first half of the century smoking was not only accepted, it was expected... The majority of society's leaders and role models smoked. Screen stars used the cigarette as an effective stage prop to convey confidence, sexuality, mystery, or a variety of moods...

... By the latter half of the century, the social environment had reversed its position... the individual is more likely to experience cognitive conflict from taking up smoking or continuing to smoke than from abstaining. ${ }^{44}$

Declines in social acceptability were linked to the spread of clean indoor air policies. Smokers exposed to smoking restrictions viewed smoking as much less socially acceptable. Even more disconcerting to the industry were the facts that smoking restrictions were increasingly popular among both non-smokers and smokers and that support for these restrictions was greater among the smokers who lived in regulated areas than smokers living in unregulated areas. ${ }^{43}$

Philip Morris conducted a "Consumer Needs Study" in the late 1980s which described four different "smokestyles" among smokers, based on smoking patterns or routines: "casual", "committed/minimal restrictions", "committed/ work restriction", and "constrained" ${ }^{45}$ With the exception of "casual" smokers, all of these "smokestyles" were daily smokers who experienced different degrees of external restriction.

"Committed/minimal restrictions" smokers did not experience home or work restrictions. Nonetheless, these smokers felt significant social pressure from non-smokers:

They said cigarettes were most enjoyable when they felt that their smoking was not bothering other people. Since they smoked constantly they found themselves in uncomfortable social situations. We heard comments like "Smoking is the only thing in life I feel odd about," "I feel weird...nonsmokers have more rights," "Smoking is getting to be a real drag." "Smoking is not as easy because of fewer places to smoke and the attitudes of nonsmokers are less tolerant." "I break the rules but this is getting harder." Typically, they had a real concern about infringing on nonsmokers. ${ }^{46}$

These smokers experienced primarily external restrictions in limited situations (restaurants, airplanes, but not at work or home) and did not internally restrict their smoking. In fact, the "lack of [internal] restrictions was a major factor affecting their sense of guilt and contributed to their feeling of being 'out of control'."46

"Committed/work restrictions" smokers were primarily affected by restrictions at work. These smokers felt that work restrictions were positive because they helped them cut down and reduced conflict with non-smokers: "No smoking in the office helps me cut down on the number of cigarettes." ${ }^{\prime 46}$ The study found that "smoking restrictions actually helped reduce smokers' guilt and helped many feel 'in control'."

"Constrained" smokers were "restricted at home by family members". Some bought by the pack to control their consumption, and "because packs required less cash out lay on a 'habit' which was not typically supported by the family. These were factors in helping them to reduce their guilt about smoking." Constrained smokers also recognised their smoking as an addiction, and felt significant guilt about it. ${ }^{46}$ The study noted that: "one possible psychological reason that smokers are adapting to or supporting restrictions is because they want to feel 'in control'. External and internal, selfimposed restrictions help them to get this feeling." ${ }^{\prime 46}$

Socially pressured smokers were an important target for tobacco marketers because they were more likely to quit. One of the reasons why smoking restrictions may encourage and support quitting is because they reduce the number of environmental cues inducing smoking. The importance of environmental cues is discussed in the same 1988 study, which was conducted when airline flights under two hours in length had just been made smoke-free. ${ }^{47}$ The report noted that under increased smoking restrictions, "fewer cues will elicit smoking behavior and more situations will be associated with refraining from smoking". ${ }^{46}$

For example, a smoker on a nonsmoking flight used to be accustom[ed] to smoking but now if the flight is under two hours the "no smoking" signs stay lit. Initially it is difficult for the smoker not to smoke but not smoking becomes easier as this new situation or cues "extinguish" the smoking response. ${ }^{46}$

Additional memos written by Philip Morris researcher Page Callaham to Dr Ed Gee in 1988 and 1990 described how smokers increasingly looked for smoking cues or refrained from smoking until someone else around them lit a cigarette. ${ }^{48} 49$

A 1989 draft report for Philip Morris on "smokers affected by legal restrictions and bans" states that smokers who changed the times and places they smoked because of restrictions tried to quit more frequently. ${ }^{50}$ While most of the quitters cited their own health as the primary reason they tried to quit, they also acknowledged that annoyance at being dependent on cigarettes, pressure from family and friends, concern about the effects of their smoke on others, and price all contributed to their decision. The report also stated that these smokers felt considerably more pressure from others to quit smoking, and that this pressure had increased in recent years. ${ }^{50}$

Another 1988 report written by Jan Jones to Dr Ed Gee hypothesised that socially acceptable products might successfully win back quitters:

It appears that a number of smokers have considered quitting. Smokers who buy by the pack rather than by the carton often explain their choice as "not knowing when I might quit." If a socially acceptable product became available, the change in behavior may be simply a change of brand. The top ranking of any new product concept 
thought to reduce health risks or social pressures support this position. ${ }^{44}$

Jones calls for Philip Morris "to develop a select group of brands designed to negate social pressures" to win back these quitters:

\section{We already have Marlboro as the brand of choice for young smokers entering the market. We do not have a product that meets the needs of the growing population of ex-smokers. Many of these ex-smokers will resume smoking, and the product that they choose could cause a swing in market share. These quitters (and those who are soon to become quitters) are dissatisfied with certain aspects of a product that previously met their needs...a textbook example of a market opportunity. ${ }^{44}$ [emphasis added]}

Jones goes on to review scientific literature addressing social influences on quitting. She concludes that these studies support the development of socially acceptable products that could "extend the social circle of smokers", alter the stigma associated with smoking, and "thereby significantly alter the product life cycle of cigarettes". ${ }^{44}$

An understanding of the needs of "socially concerned" smokers and their propensity to quit led tobacco companies to pursue numerous research projects to develop more socially acceptable tobacco products (table 1).

\section{Many smokers are interested in "socially acceptable" products}

Studies conducted for Philip Morris, British American Tobacco (BAT), and RJR all demonstrated that substantial numbers of smokers held negative views of smoking, felt uncomfortable smoking around others, and were concerned about the health effects of SHS on other people (table 2). BAT conducted extensive studies on the social acceptability of smoking starting in the early 1980s. ${ }^{51-53}$ In 1983, BAT found $79 \%$ of smokers reported they tended to smoke less when around non-smokers, ${ }^{35}$ and awareness of the health dangers of passive smoking was on the rise. ${ }^{54}$ During the 1980s Philip Morris conducted several segmentation studies on smokers and non-smokers, separating them by how strongly they felt about "smoking issues" such as the health hazards of smoking, acceptance of restrictions on smoking, and (for smokers) smoking patterns and motivations. These US studies consistently found that about half of smokers felt ambivalent or negative about smoking; two of six segments felt substantial pressure from others not to smoke (fig 2)..$^{55-57}$ Additional studies by Philip Morris ${ }^{58}$ and RJ Reynolds ${ }^{59}$ found that smokers were feeling more pressure from others to quit smoking, and that the percentage of smokers feeling "social guilt" was growing. RJR identified the "social guilt" mindset as approximately $24 \%$ of the market in 1988 , and projected that it would grow to $32 \%$ of the market by 1990 and $52 \%$ of the market by $1995 .{ }^{59}$ In 1987, RJR's research showed over $80 \%$ of smokers modified their smoking behaviour around others. ${ }^{60}$ Philip Morris's tracking studies showed the number of smokers who believed they might quit soon was rising in the late 1980s and remained at about $30 \%$ in the early 1990s. ${ }^{6162}$

\section{Demographic and psychographic characteristics of smokers interested in more socially acceptable products \\ Women}

Philip Morris tracking studies between 1986 and 1992 consistently reported that women were more likely to report they frequently felt uncomfortable about smoking and had more interest in a low sidestream product concept. ${ }^{61-63}$ They also found Spanish speaking, more affluent, and ultra low tar consumers were most uncomfortable with smoking. ${ }^{61-63}$ While one 1981 RJR study found that women may be less susceptible to anti-smoking social pressures, ${ }^{64}$ most of the subsequent RJR research found that women were more sensitive to social pressure than men and more interested in more socially acceptable cigarettes. ${ }^{64-70}$ A 1987 RJR report outlining strategic plans to develop new cigarettes, including more socially acceptable cigarettes, noted that women smokers were especially interested in these products. ${ }^{71}$ Another RJR report from 1985 explains why this might be so:

\section{- Women take social pressures and affronts much more personally; men are more likely to accept the issue, find a way to cope, and not let it bother them. \\ - Women to a greater extent than men have internalized guilt over smoking, and immediate smoke odor as well as smoke odor affereffects dredge up this guilt. ${ }^{71}$}

The same report stated that young women were more interested in "cosmetic" changes in cigarettes (improved breath, less odour, less tooth stain), while older women responded to new cigarettes that offered cleanliness or enhanced self esteem. ${ }^{71}$

\section{Young adults}

There is some evidence that younger smokers were especially vulnerable to social pressures. One report written by Jan Jones for Philip Morris noted, "Considering the 'drive' for social acceptance experienced by most people, particularly young adults, where strong anti-smoking pressures are exerted there is potential for intense cognitive dissonance" ${ }^{\prime 4}$ An RJR study from 1982 also notes that young adults exert some of the most intense social pressure:

Younger adults (18-34) are the most active anti-smokers. Younger adults are more likely to do the following antismoking activities than older adults.

- Ask someone to give up smoking

- Not put out ashtrays in home

- Cough or make some sign when someone is smoking too close

- Move away when someone smokes near them ${ }^{72}$

RJR's 1983 social acceptability of smoking report also found adults age 18-34 years were the most active antismoking age group, ${ }^{43}$ and a 1981 RJR plan reported that younger males felt that social acceptability was a more important problem than older males. ${ }^{73}$ However, a report prepared for RJR in 1983 noted that "women, people over 25, and white collar workers tend to be most sensitive to social acceptability issues, while young adults and blue collar men are more inclined to insist on their rights as a smoker". ${ }^{69}$ RJR's marketing plans for the low smoke cigarette, Salem Pianissimo, in Japan noted that social acceptability was a concern of primarily younger adults and women. ${ }^{27}$

Blue collar versus white collar

In general, higher socioeconomic status smokers appeared to be more attracted to socially acceptable products. A review of RJR's research conducted for Project CC (a reduced sidestream product) summarised:

The working environment of blue versus white collar workers has much to do with their attitudes toward social 







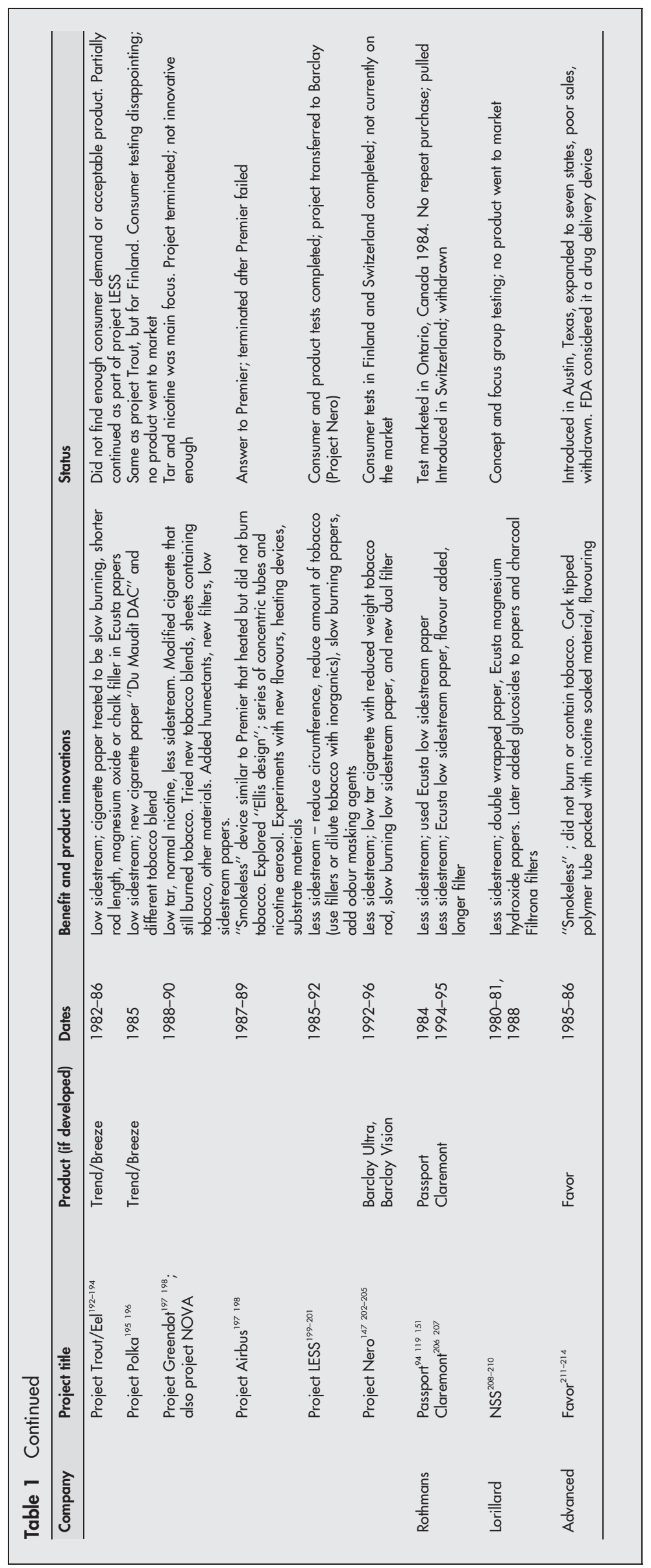

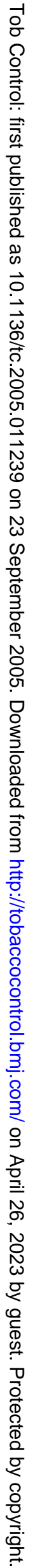


Table 2 Tobacco industry studies documenting social unacceptability of smoking

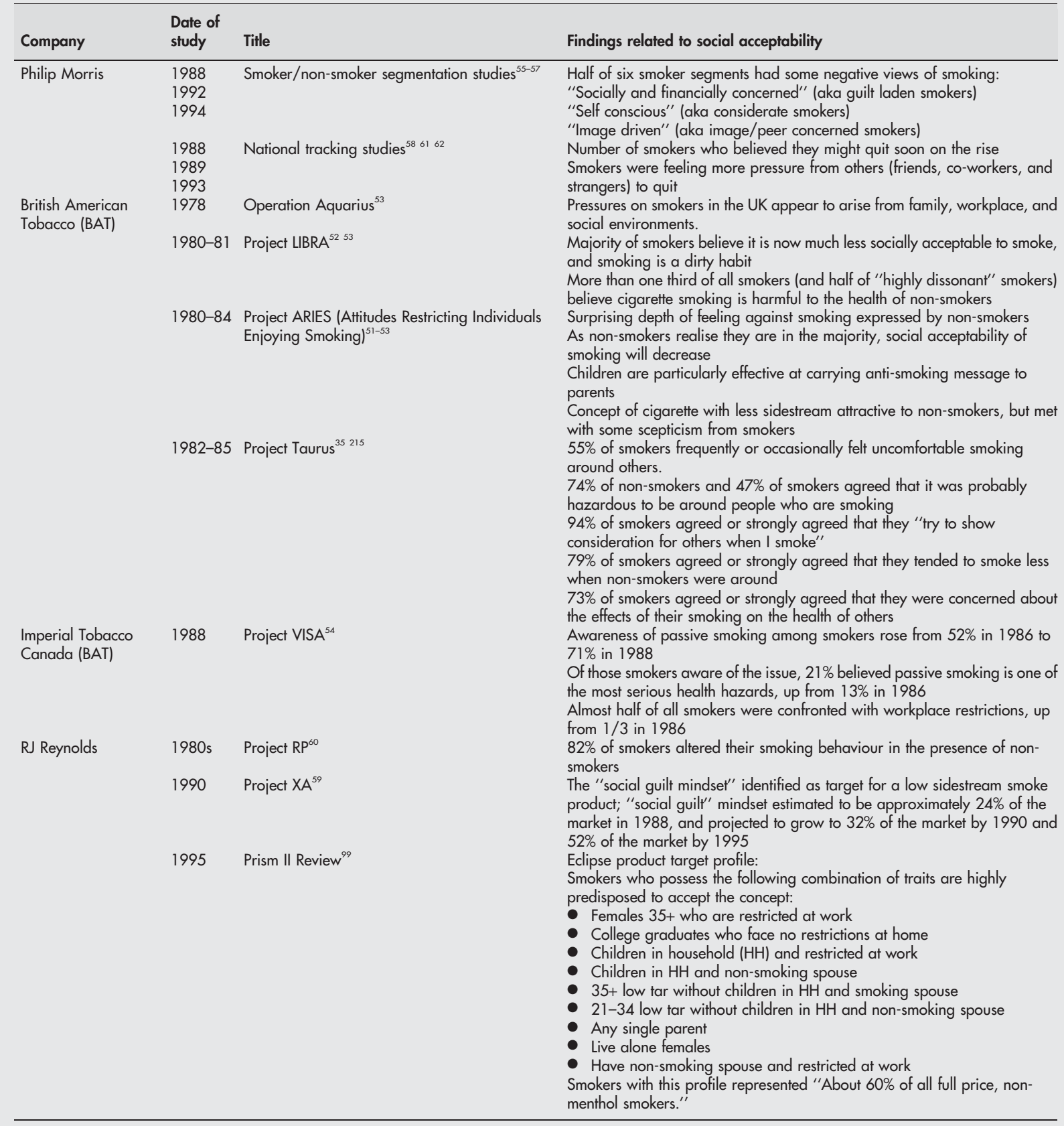

acceptability issues. Many blue collar workers are employed in unconfined environments or even outdoors. Others have occupations which, for safety reasons, prohibit smoking on the job. In either case, the blue collar worker may be confronted less frequently than the white collar worker with nonsmoker's objections to smoking in a confined environment. In addition, blue collar workers are often more adamant about their right to smoke. ${ }^{70}$

A 1989 report written for BAT including research conducted in Germany and Switzerland also noted low sidestream products could be targeted at the upper classes. ${ }^{74}$ Philip Morris's tracking studies also found more affluent consumers were more uncomfortable with smoking and more interested in the low sidestream concept. ${ }^{61-63}$
Psychographics: the "mindset"

Equally if not more important than the demographics of the target was the common "mindset" and set of values and interests that motivate the socially pressured smoker. Research conducted in 1977 for Brown \& Williamson described the socially concerned smoker psychographic as "very emotional and social person, a joiner with faith in luck" who "see themselves as disciplined, having common sense, and believe they are a little harder to impress". ${ }^{75}$ A 1981 report prepared for RJR found the following qualities made up a general psychological/attitudinal profile of the potential user of a low sidestream product:

- Concerned with other people's opinion of them

- Dislikes offending others 


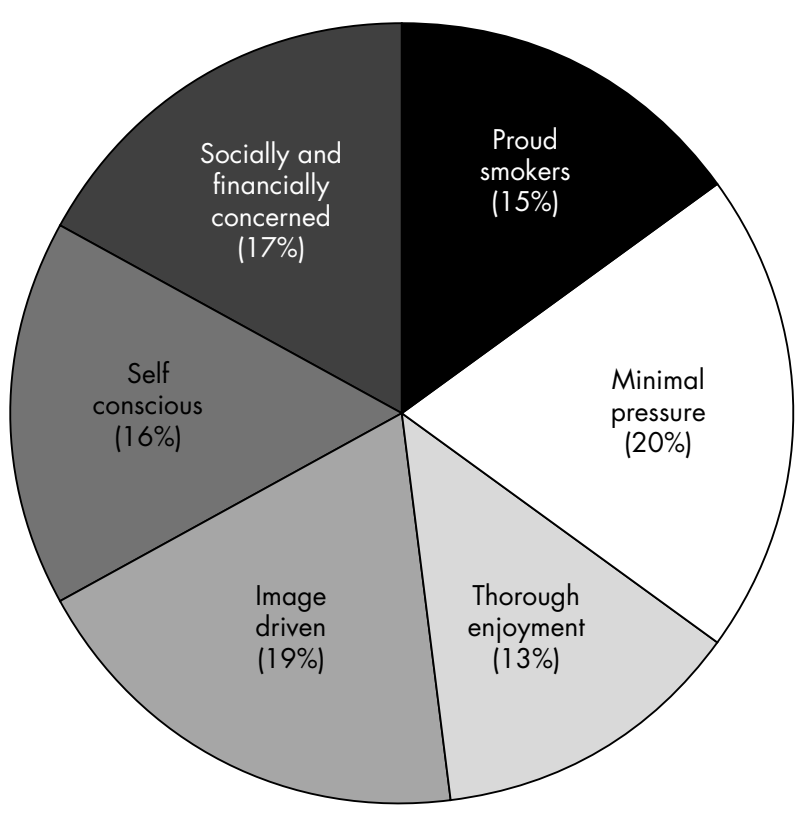

Figure 2 Segments of the 1994 US smoker population classified by attitudes about smoking. Two of the segments "self conscious" and "socially and financially concerned" feel pressure from others not to smoke, and one segment, "image driven" feels ambivalent about their smoking. ${ }^{57}$ Redrawn from figure in original document.

- Concerned with the Comfort/Health of others

- Concerned about their children

- Personally Clean/Meticulous

- Not "Macho" but still manly

- Outdoorsy Type

- Somewhat white collar

- Not for "Image Conscious" smoker

- Sociable, not a Loner ${ }^{76}$

A 1982 profile developed for RJR reiterated characteristics such as: intelligence, sensitive to the needs and approval of others, reserved, and practical. ${ }^{77}$ A 1991 report written for RJR states that the low smoke product was likely to appeal to smokers for whom "adapting to the changing smoking world and being active in coping and achieving, and feeling successful are important. [emphasis in original]" ${ }^{78}$

\section{Types of cigarette products and benefits that have been developed and their appeal to smokers}

Table 1 summarises the major efforts to develop socially acceptable cigarette products. While tobacco companies conducted research on this concept during the 1970s, we did not find actual consumer tests of new products before the 1980s.

\section{RJ Reynolds efforts}

RJR launched several of the first efforts to develop new socially acceptable cigarettes, and appears to have been the company most interested in developing new products to address social acceptability. These efforts focused on cigarettes that would have less SHS. A business opportunity analysis prepared for RJR in 1980 stated: "The consumer benefit is basically social security. That is, the ability to enjoy smoking without displeasing other people. As with all strong selling messages, this one is simple to communicate... [emphasis in original]." ${ }^{179}$ Concept testing and focus groups for "Project CC", an early low sidestream product, in 1981 revealed that the concepts were perceived as highly acceptable, with high purchase interest, importance, difference, and overall ratings. ${ }^{76}{ }^{80}$ The concept also appeared to appeal broadly to both men and women, younger and older smokers, as well as low tar and full flavour smokers. ${ }^{80}$ RJR also found several of its advertising executions for the product had higher than normal recall. ${ }^{81}$

The benefits of most low sidestream products were felt to be primarily psychological and social:

\begin{abstract}
- The smoker is more comfortable smoking in an enclosed area where others are present. This cigarette is more socially acceptable.

-The smoker feels less "dirty" about his smoking behavior. The cigarette is more elegant.

- The smoker is putting less "pollution" in the air. He feels less subject to attack by non-smokers. This cigarette reduces internal "guilt." It gets others "off his back," and it gets himself off his own back.

- The smoker feels like a more responsible, aware, considerate individual, even if others do not take notice of the low side-stream. He knows he has taken a positive step. ${ }^{82}$
\end{abstract}

Early product prototypes were generally unacceptable to smokers. RJR's product tests showed the CC prototypes were inferior in taste, and the research and development team felt that the major taste adjustments required could not be made in the short term. ${ }^{83}$

RJR's Premier is probably the best known low sidestream smoke product brought to market. "Project SPA" (which culminated in Premier) consumer tests from 1986-88 showed that, while the product concept generated a high level of trial interest, the actual product tests showed major taste deficiencies. ${ }^{84-87}$ Nonetheless, the high levels of consumer interest and some indications that the product acceptability was improving apparently led RJR to continue to develop it. RJR's advertising research indicated "the recommended campaign generated the highest level of purchase intent of any RJRT new brand advertising ever tested" and RJR planned to spend \$196 million on introductory marketing in its first year. ${ }^{88}$ RJR introduced Premier on 17 October 1988, and pulled it from the market on 29 February 1989. RJR attributed the poor performance in the market to negative publicity regarding the product's taste/aroma, "anti-smoking activists" efforts to encourage Food and Drug Administration (FDA) intervention in the marketing of Premier, and poor product performance. ${ }^{89}$

Following Premier's failure, excitement about new low sidestream brands waned. However, tobacco companies continued to pursue the idea of introducing a low sidestream product as a line extension of an established brand. RJR planned to launch a low sidestream product as a Vantage line extension, "Vantage Excel", that went to test market in 1989 and was discontinued in $1990 . .^{90-92}$

RJR also pursued several products that offered a pleasant aroma as the primary benefit. Chelsea, advertised as a "good smelling" cigarette for young women, was introduced in 1989 and discontinued in 1990.9394 Later, in 1990, the same product was resurrected as Horizon, "the first and only cigarette that can effectively reduce complaints from others, and provide an improved lingering aroma via the delivery of a pleasant aroma from the lit end". ${ }^{95}$ However, RJR focus groups revealed that advertising the "less odor" benefit tended to emphasise the problem:

Telling smokers that Horizon will make them and/or their surroundings smell better implies they currently smell unpleasant and offensive. Smokers may privately 


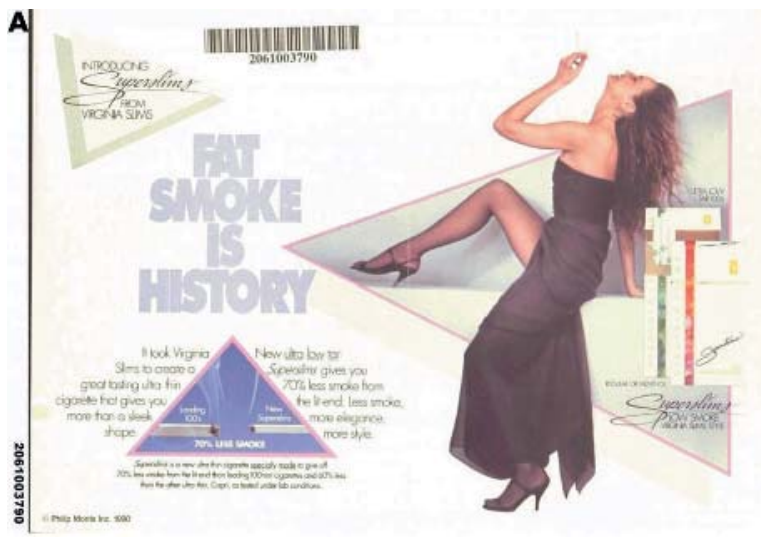

acknowledge and even openly admit this, but, as it relates to their outward smoking image and personality, may prefer not to smoke a cigarette that blatantly brands itself as a solution to an odor problem. ${ }^{96}$

Both these products were pulled from the market shortly after their introduction. Imperial Tobacco Canada conducted focus groups with smokers and non-smokers in Canada that included reactions to the Chelsea concept. In general, smokers were uninterested in the product; at worst, the masking vanilla scent was viewed as deceptive: To use a well-liked food aroma to mask a health hazard
seemed highly deceptive...

[quoting smokers verbatim] "People will object to secondhand smoke whether it's vanilla or chocolate or whathave-you."

"It seems somewhat unethical, because everyone knows about secondhand smoke. They're just trying to disguise it. $^{\prime \prime 97}$ [emphasis in original]

Smokers said they would rather not smoke than smoke a "highly compromised" product such as Chelsea: "smokers seemed a good deal more willing to resolve potential conflict problems by avoiding smoking than by smoking in an unappealing way." 97 Philip Morris focus groups also found smokers were more likely to quit or refrain from smoking than to switch to a scented product. ${ }^{98}$

RJR resurrected the idea of a low sidestream smoke cigarette (referred to occasionally as a new version of Premier) in the mid 1990s in a series of projects called "PRISM" and "PRISM 2", which eventually led to the development of the low sidestream product, Eclipse. ${ }^{99}$ RJR research in 1985 suggested that products that combined several benefits were more appealing than products touting a single benefit. ${ }^{67}{ }^{100}$ RJR began to combine multiple benefits in the new PRISM product in 1993-94. ${ }^{101}$ RJR also paid increasing attention to non-smokers' reactions, and recognised that non-smokers could potentially become advocates for the new product. RJR had tested the concept of a low sidestream product among non-smokers, and found that "Virtually all the respondents indicated they would try to persuade the smokers they are associated with to try this product. Many of the spouses of smokers said they would even buy a pack if it was available, to bring home for their husbands or wives". ${ }^{102}$ Focus groups in 1993 found that nonsmoking female spouses might encourage males to try the new product, and that some viewed the product as an aid to stop smoking. ${ }^{103}$

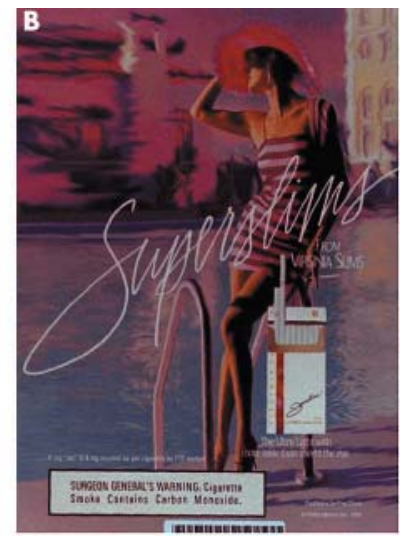

Figure 3 (A) Virginia Slims Superslims introductory 1990 advertisement emphasising the "less smoke" benefit with side-by-side cigarette comparison. ${ }^{218}$ (B) Virginia Slims Superslims advertisement in 1991. "Less smoke" benefit has been eliminated. ${ }^{219}$

\section{Philip Morris efforts}

Philip Morris's research on smokeless cigarettes also found the main benefits were: social benefits, potential health benefits, and improved hygiene/cleanliness. ${ }^{104}$ During the 1980s, Philip Morris's potentially more socially acceptable products appeared to have been developed as a defensive response to new product introductions by RJR or other tobacco companies, and these projects may have been put on hold when the new products on the market failed. Philip Morris conducted consumer tests on low sidestream products in the 1980s (Merit LS, Ambassador, Benson \& Hedges LVS), but did not introduce them to market. However, in 1988 Philip Morris planned to launch two ultra thin, low smoke, ultra low tar products: Virginia Slims Elan Thins for young fashionable women, and Benson and Hedges Select Thins for young men and women. ${ }^{105}{ }^{106}$ The advertising for Select Thins tested well in a series of 1988 interviews, ${ }^{107}$ and test markets for Select Thins and Elan were planned, ${ }^{108}$ but products appear not to have advanced beyond test markets. In 1989, Philip Morris launched Virginia Slims Superslims, a line extension that originally advertised $70 \%$ less sidestream smoke, using slogans like "Fat Smoke is History" or "Fat Smoke Just Went Up In Thin Air", and featuring a side-byside graphic comparing the smoke from Superslims to a regular cigarette ${ }^{109}$ (fig 3A). Philip Morris launched Virginia Slims Superslims in 1989 without a test market. While Superslims is still on the market in 2005, its introduction did not increase Virginia Slims's overall market share ${ }^{110}$ and its advertising stopped emphasising the "less smoke" product benefit (fig 3B).

Philip Morris also tested several scented products in response to RJR's Chelsea and Horizon, but these also appeared to have been put on hold when Chelsea and Horizon were withdrawn. In contrast to RJR's Premier and Eclipse non-burning products, Philip Morris spent several years developing a device to reduce SHS. In late 1997, Philip Morris announced limited consumer testing of Accord, a cigarette smoked with a battery powered device that reduced sidestream smoke. ${ }^{111}$ Philip Morris tested Accord with 176 adult smokers, and found that 92 chose not to take the kit home with them, 50 tried it for one week, 19 tried it for at least two weeks, and 15 continued to smoke it at the end of the study. The main characteristic that distinguished those who continued to use Accord was they tended to be the lone smoker in a non-smoking household. ${ }^{12}$ Philip Morris planned to continue to test Accord through at least 2002, ${ }^{113}$ and although Accord is still available in limited markets, it has been described as a "minimal success." ${ }^{114}$ Philip Morris also attempted to develop a low smoke cigarette as a response to Eclipse in "Project Gamma" in 1996; the product later evolved into a ceramic or foil sleeve that could be placed over 
Table 3 Why "socially acceptable" cigarettes failed

\begin{tabular}{|c|c|c|c|}
\hline Reason & Source studies & Company & Date \\
\hline \multirow{5}{*}{$\begin{array}{l}\text { It is impossible to make smoking truly socially } \\
\text { acceptable }\end{array}$} & Product Tests "Project CC" & RJR & 1981 \\
\hline & Report on Smoking Issues ${ }^{67}$ & RJR & 1985 \\
\hline & Research on Vantage Excel ${ }^{124}$ & RJR & 1991 \\
\hline & "Project XA" prototype tests ${ }^{121}$ & RJR & 1991 \\
\hline & Focus Groups on Smoking and Social Acceptability ${ }^{49}$ & PM & 1990 \\
\hline \multirow{7}{*}{$\begin{array}{l}\text { A } 100 \% \text { reduction in smoke is necessary to } \\
\text { gain a social benefit }\end{array}$} & "Project CC" product tests ${ }^{122}$ & RJR & 1981 \\
\hline & Focus Groups Project CC ${ }^{126}$ & RJR & 1985 \\
\hline & Reports summarising learning on low sidestream products ${ }^{100} 123$ & RJR & 1986 \\
\hline & Report on market share potential for low sidestream products ${ }^{124}$ & RJR & 1991 \\
\hline & Advertising Tests for Merit $\mathrm{LS}^{127}$ & PM & 1986 \\
\hline & Research on B\&H Select Thins ${ }^{125}$ & PM & 1987 \\
\hline & "Project VISA" focus groups on low sidestream products ${ }^{54}$ & Imperial & 1989 \\
\hline \multirow[t]{10}{*}{ The products taste bad } & Memo about Premier ${ }^{155}$ & PM & 1987 \\
\hline & "Project CC" product tests ${ }^{128}$ & RJR & 1981 \\
\hline & Vantage Excel product tests ${ }^{124}$ & RJR & 1991 \\
\hline & Premier Research Summary ${ }^{89}$ & RJR & 1989 \\
\hline & Research on Project $X^{131}$ & RJR & 1993 \\
\hline & Research on PRISM ${ }^{134}$ & RJR & 1993 \\
\hline & B\&H Select Thins consumer tests ${ }^{107}$ & PM & 1988 \\
\hline & Virginia Slims Superslims tests ${ }^{132}$ & PM & 1990 \\
\hline & Tests on Advance Tobacco Product's Favor ${ }^{212}$ & RJR & 1986 \\
\hline & Research on Passport ${ }^{133}$ & BAT & 1984 \\
\hline \multirow{5}{*}{$\begin{array}{l}\text { Smokers are unwilling to sacrifice their } \\
\text { own smoking pleasure to benefit others }\end{array}$} & "Project CC" focus groups 100136137 & RJR & $1983-87$ \\
\hline & Vantage Excel research ${ }^{92} 124$ & RJR & 1989 \\
\hline & Research on Passport ${ }^{133}$ & BAT & 1984 \\
\hline & Research on low sidestream products ${ }^{94}$ & BAT & 1990 \\
\hline & Research on Premier and Favor ${ }^{104}$ & PM & 1988 \\
\hline \multirow{7}{*}{$\begin{array}{l}\text { Low smoke alone is not a compelling reason to } \\
\text { buy the product } \\
\text { Reduced lit-end smoke does nothing about } \\
\text { exhaled smoke, perceived to be a bigger } \\
\text { problem }\end{array}$} & Total Proposition Tests on Vantage Excel ${ }^{124}$ & RJR & $1980 \mathrm{~s}$ \\
\hline & Memo on Virginia Slims Superslims ${ }^{132}$ & PM & 1990 \\
\hline & "Project CC" prototype tests ${ }^{217}$ & RJR & 1980s \\
\hline & Report on Socially Acceptable Products ${ }^{123}$ & RJR & 1986 \\
\hline & "Project XA" product tests ${ }^{121}$ & RJR & 1993 \\
\hline & "Project VISA" focus groups" & Imperial & 1989 \\
\hline & Report for "Project VISA" & Imperial & 1989 \\
\hline & "Project CC" research" & RJR & 1981 \\
\hline \multirow{4}{*}{ toxins for the smoker? } & "Project CC" consumer tests ${ }^{126}$ & RJR & 1985 \\
\hline & Research on Premier and Favor ${ }^{104}$ & PM & 1988 \\
\hline & "Project XA" qualitative research"102 131139 & RJR & $1990-93$ \\
\hline & Research on PRISM ${ }^{134}$ & RJR & 1993 \\
\hline
\end{tabular}

a regular cigarette to reduce sidestream smoke. ${ }^{115-117}$ Although testing continued through at least 1999, we did not find any subsequent marketing plans or advertisements for this product.

\section{BAT/Brown \& Williamson efforts}

BAT (and its US subsidiary, Brown \& Williamson) conducted research on numerous new low sidestream products, as well as tests on its competitors' new low sidestream products (table 1). However, most of these studies did not result in products going to market, as consumers often found the prototypes to be unacceptable. For example, Brown \& Williamson researchers noted "Dis-satisfaction with magnesium oxide papers due to off-taste" was a persistent problem in 1985 and recommended reconsidering whether to proceed on low sidestream products. ${ }^{118}$ BAT experimented with a nonburning tobacco heating device similar to Premier in the late 1980 s, but did not bring the product to market. BAT also tested a low sidestream Barclay line extension for introduction in Europe, including tests in Finland and Switzerland, although poor consumer response appeared to curtail these efforts.

\section{Other tobacco companies}

Small tobacco companies introduced some of the earliest products that aimed to be more socially acceptable. The first "smokeless cigarette" introduced to market in 1984 was Advanced Tobacco Product's Favor, which was not lit and actually contained no tobacco. This device was essentially a polymer tube packed with nicotine soaked filter material that delivered a nicotine aerosol. The product was widely tried at first, but subsequent sales were low, and consumer responses were disappointing. Favor was withdrawn after the FDA notified the company it regarded Favor as a drug delivery device, not a cigarette. Other early low sidestream products, such as Rothmans's Passport introduced in Canada in 1984, or Claremont in Switzerland were also pulled due to poor taste, messy ash, and lack of sales. ${ }^{54} 94119$

\section{Tobacco industry explanations for the failures of "socially acceptable" cigarette products}

Almost every attempt to develop "socially acceptable" cigarettes has failed (table 1), except for a few new products still available on the market (such as Eclipse and Accord) and some low smoke products sold with success in Japan. ${ }^{27}{ }^{120}$ Consumer research related to actual product testing by several tobacco companies reveals several common reasons why socially acceptable products have failed in the marketplace (table 3 ).

Tobacco companies consistently found that the social acceptability promised in advertising was an ideal that was impossible to achieve with actual cigarette products. $^{548394118119}$ As early as 1985 RJR found that "94\% of smokers believe that non-smokers will remain annoyed with smoking in spite of cigarette improvements". ${ }^{67}$ Finally, smokers may have found that the social benefits they expected did not follow actual use of the product, as was apparent in a series of tests conducted for RJR on "Project $\mathrm{XA}^{\prime \prime}$ in 1993: 
...the concept of "less smoke" is so attractive that both Salem and XA[a low smoke prototype product] smokers wanted to believe it, and did believe it for a while. However, about equal numbers of smokers in each cell gradually lost interest. One XA smoker summed it up by saying, "if this is what less smoke means, it isn't such a big deal. ${ }^{\prime \prime 21}$

In addition, drastic reductions in sidestream smoke were necessary to attain a benefit for smokers. Early tests for RJR's Project CC conducted in 1981 demonstrated that smokers could not readily detect the reduction in sidestream smoke in products that reduced less than $85 \%,{ }^{122}$ and studies for RJR and PM in the late 1980s found a reduction of up to $80 \%$ still did not affect purchase intent. ${ }^{123-125}$ Even though smokers might notice the difference with $85 \%$ less sidestream smoke, many of them noted that to satisfy non-smokers, anything less than an $100 \%$ reduction was unacceptable. ${ }^{49} 124126127$ In 1989 qualitative research conducted for BAT, non-smokers also reported that they would prefer to avoid cigarette smoke completely, rather than be exposed to a reduced sidestream product. ${ }^{97}$

Tobacco companies were required to modify cigarettes significantly to meet these expectations; most of the products that resulted tasted bad, or were so different from regular cigarettes that smokers found them unacceptable. RJR's attempts to develop socially acceptable cigarettes during the 1980 s and early 1990s found the prototypes' harshness, poor aftertaste, and offensive aroma made them inferior to existing cigarettes..$^{89}{ }^{128-131}$ Philip Morris also struggled with the taste characteristics of low sidestream products. ${ }^{107} 132$ Imperial's study of Passport in 1984 (test marketed by its competitor, Rothman's) also found it had a lingering metallic aftertaste that was "like sucking a coin" and "sort of silver in your mouth". ${ }^{133}$ RJR's PRISM research found "disappointment in the cigarette was extreme" with study participants complaining about "no flavor", "low smoking satisfaction", difficulty smoking the cigarette, and a "metallic" or "plastic" taste or aroma. ${ }^{134}$

Perhaps strong consumer enthusiasm for the concept and eagerness to be the first to introduce this type of product into the market led tobacco companies to bring these products to market despite this discouraging research. However, as a memo from PM brand manager S Alter to Louis Suwarna, director of new product development, noted shortly after RJR announced Premier:

\section{So a lot of hoopla over a remarkable new discovery touted to have no smoke and no tar, and which in fact tastes bad, will only reconfirm what everybody already knows about 'cleaner' cigarettes - there ain't no such thing that's worth a damn to smoke. ${ }^{135}$}

Several memos and reports for RJR emphasise that smokers were not willing to sacrifice taste for less sidestream smoke, a feature that primarily benefited others. ${ }^{92} 100136137$

By 1989, RJR's research on Vantage Excel found that as anti-smoking pressures increased, smokers were even less likely to sacrifice taste, "if I can't smoke when or where I want to, at least when I do smoke I want a cigarette that I really enjoy". ${ }^{124}$ Similarly, 1990 BAT research also concluded that smokers' unwillingness to sacrifice taste for social acceptability explained the failure of both Passport and Vantage Excel. ${ }^{94}{ }^{133}$ RJR's tests during the 1980s demonstrated the low sidestream smoke benefit was not compelling enough to motivate purchase or to compensate for taste deficiencies. ${ }^{124}$ The "low smoke" benefit Philip Morris used when it introduced the Virginia Slims Superslims line extension in 1989 was eliminated in subsequent advertising campaigns for the brand because most of those interested in trying Superslims were attracted because friends smoked it or due to promotions/coupons. The "low smoke" benefit "did not appear to have a major effect on consumer behavior" ${ }^{132} \mathrm{~A}$ report for RJR on project XA also concluded that the increase in smoking restrictions was decreasing consumer demand for socially acceptable products. ${ }^{138}$

Finally, low sidestream products generally did not address smokers' concerns about exhaled smoke ${ }^{97}$ or increased toxicity for the smoker. Reduced sidestream products generally focused on reducing the amount of smoke from the lit end of the cigarette, not exhaled smoke. RJR research on socially acceptable products noted that because products with reduced lit-end smoke still did not reduce exhaled smoke, total smoke did not appear to have been reduced sufficiently to provide a meaningful benefit. ${ }^{121}{ }^{123}$

Imperial Tobacco Canada's focus groups for "Project VISA" also found that the prototype that had the least sidestream smoke was problematic because "the extinction of one of the visual cues to smoking, sidestream smoke, focused greater attention on the remaining visual cue, exhaled mainstream smoke".${ }^{54}$ Consumers in these focus groups (erroneously) felt exhaled smoke was the main source of SHS. ${ }^{97}$ We did not find any products that claimed to reduce exhaled smoke.

Smokers were also concerned about the possibility that less sidestream smoke led to more toxins for the smoker. For example, one RJR study for Project CC in 1981 found the following smoker comments:

\section{"They are letting less of it escape and channeling more of it into the end that goes in your mouth." \\ "If they are trapping it in there, then it comes to me. If I have my choice of sharing it or keeping it, then I'd rather share it. ${ }^{176}$}

RJR's consumer tests for low sidestream products in 1985 and 1993 found that some who did not purchase the product were concerned about what "the manufacturer added to the tobacco or paper to produce less smoke" and that this would make the cigarette either less satisfying or more hazardous. ${ }^{126}{ }^{131}$ These studies also found that smokers perceived prototypes with "black pieces in the blend and the black inner liner" to be artificial and less appealing than "natural" appearing products. ${ }^{102}$ However, when the black substance was compared to the charcoal in water filters, smokers' concerns were alleviated. ${ }^{139}$ In December 2004, advertising on the Eclipse website included a cross section of the cigarette (none of the parts are black). The explanation offered was, "Eclipse works much like a coffeemaker, which passes hot water through coffee grounds to release the flavor". ${ }^{18}$

\section{DISCUSSION}

The tobacco companies' consumer research on socially acceptable products and their failure to develop and market a successful product helps explain why education on the dangers of SHS and creation of smoke-free environments is such an effective tobacco control policy. This research also helps to explain the large reduction in smoking prevalence and consumption levels among continuing smokers when workplaces $^{140}$ and homes ${ }^{141} 142$ are made smoke-free as well as why the popularity of these measures grows after their implementation. ${ }^{143-145}$ In fact, tobacco companies like RJR understood these facts as long ago as 1983, well before most in the public health community understood it:

The first fact that emerged from the research we conducted is that a majority of all adults want smoking restrictions in 
public places. We asked people if they would vote for legislation that would restrict public smoking. Of all adults, $66 \%$ agreed they would vote for such legislation. Even $44 \%$ of smokers agreed with this statement. What was even more surprising for us to find was that smokers who live in regulated areas want restrictions more than do smokers who live in non-regulated areas. ${ }^{43}$ [italic emphasis added]

While these smokers represent a major-and difficult to address-problem for the tobacco industry, it represents an attractive and straightforward opportunity for intervention by public health programmes. In response to these pressures, tobacco companies invested heavily in numerous efforts to develop more socially acceptable tobacco products. These efforts were encouraged by consumer research showing the concept of such a product was extremely popular among smokers, particularly women, higher income, and possibly young adults. More important, these products appealed to the large and increasing numbers of smokers who felt uncomfortable smoking around others. In their efforts, tobacco companies found the power of suggestion created by advertising was very strong. For example, RJR's product tests in 1993 comparing a low sidestream "Project XA" prototype to a "control" Salem cigarette (with its usual amount of sidestream smoke) revealed that after viewing advertising participants perceived both products to have less smoke:

The power-of-suggestion was very strong and resulted in about equal numbers of people in each cell recognizing "less smoke" benefits. There were people in both the Salem and XA cells who subjected their cigarettes to rigorous tests and were absolutely convinced that they had less smoke. ${ }^{121}$

Despite the persuasive effect of advertising, tobacco companies were not able to develop new "socially acceptable" products that translated into significant consumer purchase. ${ }^{146}$ When actual products were tested, enthusiasm for them consistently waned.

Most low sidestream products tasted or smelled inferior to regular cigarettes, and smokers were unwilling to sacrifice their smoking experience to benefit others. In addition, the new products did not actually confer social acceptability on smokers; only a completely smokeless product (eliminating both sidestream and exhaled smoke) might achieve this. Smokers were also concerned about the safety of these products (table 3)..$^{76} 126131$ The numerous faults and limitations of these products also provides an opportunity for public health campaigns to educate the public about these problems, which may undermine the marketing campaigns designed to drive demand for these products as an alternative to quitting.

While the bulk of the consumer research in this analysis took place in the USA, tobacco industry concerns about the social acceptability of smoking are evident in many different countries. While it cannot be assumed that the smoking dynamics observed in the North American markets can be readily transferred to all international contexts, transnational tobacco companies have monitored social acceptability in numerous countries worldwide, and have investigated how to introduce new products where it seems viable. For example, BAT planned to test more socially acceptable products in Europe in response to growing recognition of environmentalism in Finland, and potential for low sidestream products in Switzerland. ${ }^{147}$ While European consumers may have had the same problems with the product that

\section{What this paper adds}

Most of the prior research on the tobacco industry and the social acceptability of smoking focuses on industry efforts to undermine the scientific evidence on the health hazards of secondhand smoke or public relations efforts to affect societal views of smoking and smokers. The tobacco industry also invested heavily in addressing social acceptability through marketing strategies, especially in attempts to develop new, more socially acceptable cigarettes. Prior studies of "low odour" or "low sidestream" products have focused on the product contents; this study examines the marketing of these products, and the consumer research tobacco companies conducted during their development.

Tobacco industry consumer research shows great consumer interest in cigarettes that lack secondhand smoke, but tobacco companies repeatedly failed to develop acceptable cigarette products that could deliver on their advertising promises. These studies also provide new insights into smoking behaviour, including how and why smoking restrictions motivate smoking cessation, and why they are increasingly popular among both smokers and non-smokers when enacted.

were found in North American studies, this was not universally true. Although RJR's low sidestream products failed in the USA, they were able to introduce the low sidestream product, Salem Pianissimo, with fair success in Japan in 1995, and in 1996 and 1997 both Philip Morris and Japan Tobacco followed with low smoke/low odour products such as Virginia Slims One, or Bevel Flair in Japan. ${ }^{14-150}$ The potential success of socially acceptable cigarette products, as well as the potential success of clean air policies, warrants additional international attention.

The tobacco industry's research yields strong guidance for public health professionals designing tobacco control programmes. A focus on SHS and the right of non-smokers to clean air will decrease the size of the markets for potentially more socially acceptable products, particularly since most socially concerned smokers are very supportive of smoking restrictions, and generally favour them over new products. Both smokers and non-smokers prefer clean air policies to "socially acceptable" products, and the more widespread clean air policies, the stronger the support for these policies.

\section{ACKNOWLEDGEMENTS}

The authors would like to thank Drs Jeffrey Wigand, Michael Cummings, and Pascal Diethelm for their helpful comments on the manuscript.

\section{Authors' affiliations}

P M Ling, Department of Medicine, Division of General Internal Medicine, Center for Tobacco Control Research and Education, University of California, San Francisco, USA

S A Glantz, Department of Medicine, Division of Cardiology, Center for Tobacco Control Research and Education, Institute for Health Policy Studies, Cardiovascular Research Institute, University of California, San Francisco, USA

This work was supported by National Cancer Institute Grants CA-87472 and CA-61021 and the Flight Attendant Medical Research Institute

Competing interests: none declared

\section{REFERENCES}

1 Roper Organization. A Study of Public Attitudes toward Cigarette Smoking and the Tobacco Industry in 1978; Volume I May 1978. May 1978. Bates No. TIMN0161665/1718. Minnesota AG. http://legacy.library.ucsf.edu/ $\mathrm{tid} / \mathrm{vdr} 82 \mathrm{FOO}$. (Accessed 17 Mar 2004). 
2 Barnes DE, Hanaver P, Slade J, et al. Environmental tobacco smoke. The Brown and Williamson documents. JAMA 1995;274:248-53.

3 Hong MK, Bero LA. How the tobacco industry responded to an influential study of the health effects of secondhand smoke. BMJ 2002;325:1413-6.

4 Barnes DE, Bero LA. Industry-funded research and conflict of interest: an analysis of research sponsored by the tobacco industry through the Center for Indoor Air Research. J Health Polit Policy Law 1996;21:515-42.

5 Ong EK, Glantz SA. Constructing "sound science" and "good epidemiology": tobacco, lawyers, and public relations firms. Am J Public Health 2001;91:1749-57.

6 Neilsen K, Glantz SA. A tobacco industry study of airline cabin air quality dropping inconvenient findings. Tobacco Control 2004;13(suppl I):i20-9.

7 Muggli ME, Forster JL, Hurt RD, et al. The smoke you don't see: uncovering tobacco industry scientific strategies aimed against environmental tobacco smoke policies. Am J Public Health 2001;91:1419-23.

8 Glantz SA. Achieving a smokefree society. Circulation 1987;76:746-52.

9 Ong EK, Glantz SA. Tobacco industry efforts subverting International Agency for Research on Cancer's second-hand smoke study. Lancet 2000;355: 1253-9.

10 Magzamen S, Glantz SA. The new battleground: California's experience with smoke-free bars. Am J Public Health 2001;91:245-52.

11 Trotter L, Chapman S. "Conclusions about exposure to ETS and health that will be unhelpful to us": how the tobacco industry attempted to delay and discredit the 1997 Australian National Health and Medical Research Council report on passive smoking. Tobacco Control 2003;12(suppl III):iii102-6.

12 Muggli ME, Hurt RD, Becker LB. Turning free speech into corporate speech: Philip Morris' efforts to influence U.S. and European journalists regarding the U.S. EPA report on secondhand smoke. Prev Med 2004;39:568-80.

13 Drope J, Bialous SA, Glantz SA. Tobacco industry efforts to present ventilation as an alternative to smoke-free environments in North America. Tobacco Control 2004;13(suppl I):i41-7.

14 Dearlove JV, Bialous SA, Glantz SA. Tobacco industry manipulation of the hospitality industry to maintain smoking in public places. Tobacco Control 2002;11:94-104.

15 Pilkington P, Gilmore AB. The Living Tomorrow Project: how Philip Morris has used a Belgian tourist attraction to promote ventilation approaches to the control of second hand smoke. Tobacco Control 2004;13:375-8.

16 Maxwell JC. The Maxwell Report Year End \& Fourth Quarter 20030000 Sales Estimates for the Cigarette Industry. Feb 2004. Bates No. 80893292/ 3311. http://legacy.library.ucsf.edu/tid/ddf45a00. (Accessed 11 Jan 2005).

17 Stratton K, Shetty P, Wallace R, Bondurant S, Institute of Medicine. Clearing the smoke: assessing the science base for tobacco harm reduction. Washington DC: National Academies Press, 2001.

18 RJ Reynolds. Eclipse; 2004. www.eclipse.rjirt.com. (Accessed 30 Nov 2004).

19 Pollay RW, Dewhirst T. The dark side of marketing seemingly "Light" cigarettes: successful images and failed fact. Tobacco Control 2002;11(suppl I):i18-31.

20 Pollay RW, Dewhirst T. Marketing cigarettes with low machine-measured yields. In: Risks associated with smoking cigarettes with low machinemeasured yields of tar and nicotine. Bethesda, Maryland: US Department of Health and Human Services, National Institute of Health, National Cancer Institute, 2001

21 Pollay RW, Dewhirst T. A Premiere example of the illusion of harm reduction cigarettes in the 1990s. Tobacco Control 2003;12:322-32.

22 Leavell NR. The low tar lie. Tobacco Control 1999;8:433-7.

23 Pauly JL, Mepani AB, Lesses JD, et al. Cigarettes with defective filters marketed for 40 years: what Philip Morris never told smokers. Tobacco Control 2002;11 (suppl I):i51-61.

24 King W, Carter SM, Borland R, et al. The Australian tar derby: the origins and fate of a low tar harm reduction programme. Tobacco Control 2003;12(suppl III):iii61-70.

25 Connolly GN, Wayne GD, Lymperis D, et al. How cigarette additives are used to mask environmental tobacco smoke. Tobacco Control 2000;9:283-91.

26 Collishaw N. Manipulation. The story of imperial tobacco and its cigarettes Ottawa: Physicians for a Smoke-free Canada, 1999, http://www.smokefree.ca/pdf $1 /$ manipulatione.pdf.

27 Assunta M, Chapman S. A "clean cigarette" for a clean nation: a case study of Salem Pianissimo in Japan. Tobacco Control 2004;13(suppl II):ii58-62.

28 Leo Burnett Agency. Virginia Slims Agency Overview. 14 Jul 1994. Bates No. 2040144325/4395. http://legacy.library.ucsf.edu/tid/uyf75e00. (Accessed 11 Jan 2005).

29 Malone RE, Balbach, ED. Tobacco industry documents: treasure trove or quagmire? [Comment in: Tobacco Control 2000;9:261-2]. Tobacco Control 2000;9:334-8

30 Francey N, Chapman S. "Operation Berkshire": the international tobacco companies' conspiracy. BMJ 2000;321:371-4

31 Needham DFL. Gallaher. ICOSI Social Acceptability Survey in 11 Countries. 16 May 1978. Bates No. 2024260783/0785. http:// legacy.library.ucsf.edu/tid/xzl98e00. (Accessed 26 Apr 2005)

32 Cullman (inferred) H. Speech on ICOSI from Latin America/lberia Region Marketing Conference. 14 Sep 1979. Bates No. 2501018276/8292. http://legacy.library.ucsf.edu/tid/lqr22e00. (Accessed 26 Apr 2005).

33 Anon. Burson-Marstellar. Social Acceptability of Smoking and of Smokers - a Strategic Approach for Philip Morris International. Nov 1991. Bates No. 2023000218/0223. http://legacy.library.ucsf.edu/tid/mtq98e00. (Accessed 26 Apr 2005)

34 van Gorkham TM. Rothmans International. Mission and Role of ICOSI. 21 May 1979. Bates No. 2023024571/4580. http://legacy.library.ucsf.edu/ tid/ews24e00. (Accessed 26 Apr 2005).
35 Wessel PS. Project Taurus. 19 May 1983. Bates No. 103020669103020681. http://bat.library.ucsf.edu/tid/gum00a99. (Accessed 6 April 2004).

36 McCann-Erickson. New Brand Development For Cigarettes. An Examination of the Marketing Oppurtunity by Smoker Attitude Segments. Aug 1977. Bates No. 757000349/0412. http://legacy.library.ucsf.edu/tid/scx03f00. (Accessed 19 Jan 2005).

37 Durden D. Discussion Paper Social Acceptability of Smoking What Factor Influenced the Trends Shown in the Assessment Model (for the U.S.). 25 Jul 1977. Bates No. 2025025080/5082. http://legacy.library.ucsf.edu/tid/ wla81f00. (Accessed 19 Jan 2005).

38 Gaspar AP. Social Acceptability. 27 Jan 1978. Bates No. 500358205/ 8206. http://legacy.library.ucsf.edu/tid/umj77c00. (Accessed 19 Jan 2005).

39 McKee MK, Marketing Development Dept. Social Acceptability of Smoking 11 May 1982. Bates No. 507546368/6369. http:// legacy.library.ucsf.edu/tid/obl24d00. (Accessed 19 Jan 2005)

40 McKee MK, Marketing Development Dept. Social Acceptability of Smoking. 1 Sep 1982. Bates No. 507546303/6307. http://legacy.library.ucsf.edu/ $\mathrm{tid} /$ ibl24d00. (Accessed 19 Jan 2005).

41 De Garmo Inc. Lorillard "Next Era" Presentation. 6 Jun 1979. Bates No. 01353526/3665. http://legacy.library.ucsf.edu/tid/owr91 e00. (Accessed 11 Jan 2005).

42 Hudson AW. Socially Acceptable Cigarette. 8 Nov 1979. Bates No. 00360191/0193. http://legacy.library.ucsf.edu/tid/vkl88d00. (Accessed 11 Jan 2005).

43 Fackelman (inferred) E. Smoking Attitudes Study. 7 Jan 1983. Bates No. 502771897/1974. http://legacy.library.ucsf.edu/tid/uhh78d00. (Accessed 06 Apr 2004).

44 Jones J. Statement of Position on the Social Pressures Construct. June 20 1988. Bates No. 2050801835/1853. legacy.library.ucsf.edu. (Accessed May 3, 2002)

45 Anon. Consumer Needs Research. 1988 (inferred). Bates No. 2057041683/1698. legacy.library.ucsf.edu. (Accessed May 13, 2002)

46 Anon. Untitled (draft report on Consumer Needs Study qualitative and quantitative findings). July 1988. Bates No. 2057041812/1833. http:// legacy.library.ucsf.edu/tid/acp96e00. (Accessed May 13, 2002)

47 Holm AL, Davis RM. Clearing the airways: advocacy and regulation for smoke-free airlines. Tobacco Control 2004;13(suppl I):i30-6.

48 Callaham P. Consumer Needs Research - "Smokeless" Cigarette Concept. August 8 1988. Bates No. 2024068946/8953. http:// legacy.library.ucsf.edu/tid/ldr14e00. (Accessed May 13, 2002).

49 Callaham P. Philip Morris. Consumer Needs Focus Groups. 17 Apr 1990 Bates No. 2022217012/7015. http://legacy.library.ucsf.edu/tid/ yyp58e00. (Accessed 20 Jan 2005).

50 Anon. Smokers Affected by Legal Restrictions and Bans. December 1989. Bates No. 2049141250/1279. http://legacy.library.ucsf.edu/tid/ zju95e00. (Accessed May 7, 2002).

51 Anon. Psychology and Sensory Testing. 1982. Bates No. 100163710 10016371 1. http://bat.library.ucsf.edu//tid/tfg72a99. (Accessed 10 May 2005).

52 Anon. Batco. Smoking and Health Research. 1980s (est.). Bates No. 302001743-302001761. http://bat.library.ucsf.edu//tid/lto82a99. (Accessed 10 May 2005)

53 Ayres CI. Group R, Development C. Discussion on Sidestream. 31 Mar 1980. Bates No. 100510560-100510564. http://bat.library.ucsf.edu// $\mathrm{tid} / \mathrm{kcl00a99}$. (Accessed 11 May 2005).

54 Brohr C. Project VISA. 16 Feb 1989. Bates No. 500266213-500266228 http://bat.library.ucsf.edu//tid/paw90a99. (Accessed 11 Jan 2005).

55 Philip Morris. How Today's Smokers Feel About Smoking Issues. Mar 1988 (est.) Bates No. 2001260000/0114. http://legacy.library.ucsf.edu/tid/ nfa88e00. (Accessed 19 Jan 2005)

56 Philip Morris. The 910000 Study of Smokers' and Non-Smokers' Attitudes. Jan 1992. (est.) Bates No. 2024790388/0472. http:// legacy.library.ucsf.edu/tid/jxk04e00. (Accessed 19 Jan 2005)

57 Philip Morris. Smoker Non-Smoker Segmentation Study. 24 Feb 1994. Bates No. 2045165478/5583. http://legacy.library.ucsf.edu/tid/wxl55e00. (Accessed 19 Jan 2005).

58 Anon. The impact of legal bans and restrictions, social pressure, and family pressure on smoking and smokers. October 23 1989. Bates No. 2049141280/1373. http://legacy.library.ucsf.edu/tid/aku95e00. (Accessed May 7, 2002)

59 Anon. Project XA. 13 Nov 1990. Bates No. 507543276/3283. http:// legacy.library.ucsf.edu/tid/bjl24d00. (Accessed 19 Jan 2005).

60 Herberger JA. Project RP - Status/Development Plan. 5 May 1987. Bates No. 506450155/0161. http://legacy.library.ucsf.edu/tid/ith64d00. (Accessed 19 Jan 2005).

61 Isaacs J. Philip Morris. Social Acceptability of Smoking. 20 Jan 1988. Bates No. 2041132166/2167. http://legacy.library.ucsf.edu/tid/aet66e00. (Accessed 19 Jan 2005).

62 Gordon RW. Philip Morris. Social Acceptability of Smoking. 22 Mar 1993. Bates No. 2060003438/3440. http://legacy.library.ucsf.edu/tid/ aor76e00. (Accessed 19 Jan 2005)

63 Neary A. Pm PM. Low Sidestream Cigarette. 7 Feb 1986. Bates No. 206001 1020/1022. http://legacy.library.ucsf.edu/tid/ywj52e00. (Accessed 20 Jan 2005).

64 Anon. 1981 (810000) Segmentation Study Findings on Social Acceptability of Smoking. 1981. (est.) Bates No. 502674461/4463. http:// legacy.library.ucsf.edu/tid/pul78d00. (Accessed 20 Jan 2005) 
65 Anon. Project CC Positioning Statement. 1981. (est.) Bates No. 503717597/ 7601. http://legacy.library.ucsf.edu/tid/ell85d00. (Accessed 20 Jan 2005).

66 Anon. New Brands Opportunities and Supporting Technologies. 1986. (est.) Bates No. 505938957/8984. http://legacy.library.ucsf.edu/tid/jyc94d00. (Accessed 20 Jan 2005).

67 Cambridge Group. R. J. Reynolds Tobacco Company Smoking Issues. 18 Jul 1985. Bates No. 502786669/6710. http://legacy.library.ucsf.edu/tid/ qcg78d00. (Accessed 20 Jan 2005).

68 Cambridge Group. RJRT and the Cambridge Group Agree That There Are Four Clear Areas Which Have Emerged as Opportunities in Social Acceptability. 1985. (est.) Bates No. 505218317/8318. http:// legacy.library.ucsf.edu/tid/ijs25d00. (Accessed 20 Jan 2005).

69 Carol Bernstein Research. Social Acceptability Exploratory Study Social Acceptability Imagery Room Aroma. Apr 1983. (est.) Bates No. 505754198/4261. hitp://legacy.library.ucsf.edu/tid/jeu05d00 (Accessed 20 Jan 2005).

70 Anon. Demographic/Psychographic Appeal of SA Projects. Mar 1984. Bates No. 504662625/2628. http://legacy.library.ucsf.edu/tid/ zdb65d00. (Accessed 11 Jan 2005).

71 Anon. New Brands Opportunities and Supporting Technologies. 1987. Bates No. 506786513/6540. http://legacy.library.ucsf.edu/tid/hhh44d00. (Accessed 16 Mar 2004)

72 Anon. Smoking Attitudes Study. Social Acceptability. 1982. Bates No. 502674370/4396. http://legacy.library.ucsf.edu/tid/kul78d00. (Accessed September 16, 2002).

73 Holt SE, Marketing Development Dept. Target for Project "CC". 26 Jan 1981. Bates No. $500793911 / 3912$. http://legacy.library.ucsf.edu/tid/ rch69d00. (Accessed 20 Jan 2005).

74 PCO K. International Brand Strategy for Offensive use of Low Sidestream Paper. 06 Dec 1989. Bates No. 403716613-403716616. http:// bat.library.ucsf.edu//tid/gyp00a99. (Accessed 20 Jan 2005).

75 McCann Erickson. New Brand Development For Cigarettes. An Examination Of The Marketing Opportunity By Smoker Attitude Segments. Aug 1977 (est.) Bates No. 757000349/0412. http://legacy.library.ucsf.edu/tid/ scy03f00. (Accessed 20 Jan 2005).

76 Carol Bernstein Research. Final. Project CC Study Mdd\#81-2487. Jun 1981. (est.) Bates No. 500049189/9245. hittp://legacy.library.ucsf.edu/ tid/ihd99d00. (Accessed 20 Jan 2005).

77 RJR. Project CC Marketing Plan Overview. Project CC Target Profile. Positioning Statement. 6 Aug 1982. Bates No. 504028214/8219. http:// legacy.library.ucsf.edu/tid/wdh75d00. (Accessed 20 Jan 2005).

78 Gene Shore Assoc. R.J. Reynolds Project XA April, 1991 (910400). Apr 1991. (est.) Bates No. 508996375/6398. http://legacy.library.ucsf.edu/ tid/jam83d00. (Accessed 20 Jan 2005).

79 First Team Ventures. Project CC. Opportunity Analysis. August 12, 1980 (800812). 12 Aug 1980. Bates No. 504455564/5574. http:// legacy.library.ucsf.edu/tid/git77c00. (Accessed 11 Jan 2005).

80 Hunter CS. RJ Reynolds. New Business Research and Development Report. Final. Project CC Concept Test (Mdd \#81-2488). 7 Aug 1981. Bates No. 500049270/9295. http://legacy.library.ucsf.edu/tid/mhd99d00. (Accessed 20 Jan 2005).

81 Anon. RJ Reynolds. Project CC. Positioning and Creative Development. 10 Mar 1983. Bates No. 503717291/7315. http://legacy.library.ucsf.edu/ tid/tkl85d00. (Accessed 20 Jan 2005).

82 Anon. Project CC Fact Book Table of Contents. 1900. (est.) Bates No. 503807094/7143. http://legacy.library.ucsf.edu/tid/bkr77c00. (Accessed 20 Jan 2005).

83 McCaffrey KV. Project CC Status. 16 Mar 1983. Bates No. 516687062/ 7063. http://legacy.library.ucsf.edu/tid/ftd97c00. (Accessed 20 Jan 2005).

84 Whitlatch WP. RJ Reynolds. New Business Research and Development Report. Project SPA Concept/Product Qualitative Research. 17 Oct 1986. Bates No. 505942757/2762. http://legacy.library.ucsf.edu/tid/ brb94d00. (Accessed 20 Jan 2005).

85 Toben TP, RJ Reynolds. New Business Research and Development Report. Project SPA Product Acceptance Screening. $15 \mathrm{Dec}$ 1987. Bates No. 506244326/4355. http://legacy.library.ucsf.edu/tid/jzz77c00. (Accessed 20 Jan 2005).

86 Cohen PS, RJ Reynolds. New Business Research and Development Report. Project SPA Adaptation and Acceptance Test. 4 May 1988. Bates No. 506373093/31 18. http://legacy.library.ucsf.edu/tid/cwh74d00. (Accessed 20 Jan 2005).

87 Cohen PS, RJ Reynolds. PN\# 88-11101. New Business Research \& Development Report. Project SPA Adaptation and Acceptance Test. $5 \mathrm{Apr}$ 1988. Bates No. 506728403/8427. http://legacy.library.ucsf.edu/tid/ run44d00. (Accessed 20 Jan 2005).

88 Kampe RA, Hayes AW. Project SPA Presentation. Board of Directors. 21 Jul 1988. Bates No. 514848159/8198. http://legacy.library.ucsf.edu/tid/ zwz61d00. (Accessed 20 Jan 2005).

89 Cohen PS. RJR. Marketing Research Report. Comprehensive Overview of Consumer Reactions to Premier. 11 May 1989. Bates No. 510331818/ 1845. http://legacy.library.ucsf.edu/tid/ahg63d00. (Accessed 4 Jan 2005).

90 Bewley LA. Introduction of Vantage Excel 100's. 13 Dec 1988. Bates No. 515834110/41 10. http://legacy.library.ucsf.edu/tid/jdg92d00. (Accessed 20 Jan 2005)

91 Faggert TL, RJ Reynolds. Product Research Report. Project VRP/Beta and Project XGT Qualitative Research Final Report. 5 Jan 1990. Bates No. 509165221/5239. http://legacy.library.ucsf.edu/tid/asz73d00 (Accessed 20 Jan 2005).
92 Anon. Project VRP. 13 Oct 1989. Bates No. 510906853/6868. http:// legacy.library.ucsf.edu/tid/gzp53d00. (Accessed 20 Jan 2005).

93 Robinson AL. Review of Qualitative and Quantitative Research on Chelsea and Horizon. 22 Oct 1992. Bates No. 508968022/8048. http:// legacy.library.ucsf.edu/tid/rcn83d00. (Accessed 12 Jan 2005).

94 Deines WM, Templeton LK, Charles FK. Cigarette Sidestream. 05 Aug 1990. Bates No. 201829984-201829989. http://bat.library.ucsf.edu//tid/ tms00a99. (Accessed 11 Jan 2005).

95 Young Rubicam. Horizon Strategic Marketing Review. 1 Oct 1990. Bates No. 517041951/2003. http://legacy.library.ucsf.edu/tid/yzt03a00. (Accessed 20 Jan 2005).

96 Mindy Goldberg Assoc. Overview of Strategic Positioning Issues for Horizon. Aug 1991. (est.) Bates No. 516903836/3843. http:// legacy.library.ucsf.edu/tid/idu03a00. (Accessed 20 Jan 2005)

97 Perception Research Inc. Project Visa. Jun 1989. (est.) Bates No. 465717745/7790. http://legacy.library.ucsf.edu/tid/gwm01 foO. (Accessed 16 Jan 2005).

98 Callaham P. Philip Morris. Ambrosia II (Aromatek 245) Focus Groups. 19 Oct 1990. Bates No. 2024068754/8763. http://legacy.library.ucsf.edu/ $\mathrm{tid} / \mathrm{xph85e00.}$. Accessed 20 Jan 2005).

99 Anon. Prism II Review. Mar 1995. (est.) Bates No. 514301008/1021 http://legacy.library.ucsf.edu/tid/hpz87c00. (Accessed 20 Jan 2005).

100 Anon. B. Social Acceptability III. Detailed Findings. Oct 1986. (est.) Bates No. 505931138/1139. http://legacy.library.ucsf.edu/tid/sbd94d00 (Accessed 20 Jan 2005).

101 Nicolas Resesarch Assoc Intl. Summary Report for a Qualitative Study on Project CC and Project SS. 10 Nov 1993. Bates No. 514305299/5342. http://legacy.library.ucsf.edu/tid/fxd13d00. (Accessed 12 Jan 2005).

102 Wolf Altschul Callahan. Project XA - Atlanta (10/29,30,31). Nov 1990. (est.) Bates No. 507543517/3537. http://legacy.library.ucsf.edu/tid/ iil24d00. (Accessed 20 Jan 2005).

103 BRM Research. Project Prism 2 Qualitative Exploration of Smoker/Non Smoker Issues for Communication Development. Management Summary. 1992. Bates No. 514284108/41 14. http://legacy.library.ucsf.edu/tid/ jae13d00. (Accessed 12 Jan 2005).

104 Callaham P. Philip Morris. Review of Consumer Research on Nonburning Smokeless Cigarette. 12 Sep 1991. Bates No. 2051564564/4565. http:// legacy. library.ucsf.edu/tid/hsx52e00. (Accessed 20 Jan 2005).

105 Jannetta SPM. Benson and Hedges Select Thins. Test Market Introduction. 18 Jul 1988. Bates No. 681941961/1972. http://legacy.library.ucsf.edu/tid/ glp03f00. (Accessed 20 Jan 2005).

106 Anon. Select Thins from Benson \& Hedges. Feb 1988. (est.) Bates No. 204421 1363. http://legacy.library.ucsf.edu/tid//sp55e00. (Accessed 20 Jan 2005).

107 Gurry N. Philip Morris. Marketing Research Department Report B\&H Select Thins Ad Pack Study. 12 Oct 1988. Bates No. 2042480347/0409. http:// legacy.library.ucsf.edu/tid/eye03e00. (Accessed 20 Jan 2005).

108 Anon. Media Status Report 880100. Jan 1988. (est.) Bates No. 2040733554/3568. http://legacy.library.ucsf.edu/tid/cwe04e00. (Accessed 20 Jan 2005).

109 Anon. Philip Morris. Philip Morris U.S.A. -Submission to Corporate Products Committee Monthly Meeting Of: 890600 . Jun 1989. (est.) Bates No. 2024269628/9629. http://legacy.library.ucsf.edu/tid/llk85e00. (Accessed 20 Jan 2005).

110 Toll BA, Ling PM. The Virginia Slims identity crisis: an inside look at tobacco industry marketing to women. Tobacco Control 2005;14:172-80.

111 Pollack J. Philip Morris Tries Smokeless Accord Tobacco Marketer, Cautious About Brand, Doing 'Consumer Research'. Oct 1997. (est.) Bates No. 2074137658. http://legacy.library.ucsf.edu/tid/eqc76c00. (Accessed 16 Jan 2005).

112 Jones J. Final Report On Accord First Placement Study. 20 Mar 1998. Bates No. 2064703192/3200. http://legacy.library.ucsf.edu/tid/iil45d00. (Accessed 16 Jan 2005).

113 Philip Morris USA. Accord Product Communications Prior Exploratory Studies and Proposed Research Plan. 20 Apr 2001. Bates No. 2080507394/7397. http://legacy.library.ucsf.edu/tid/nar14c00. (Accessed 16 Jan 2005)

114 Wahlberg D. Smoking: Products claim to lower risks. Atlanta Journal Constitution 20043 October 2004 URL. http://www.ajc.com/news/ content/health/1004/04smoking.html.

115 Anon. Project Gamma. 1995. (est.) Bates No. 2059666101/61 12. http:// legacy.library.ucsf.edu/tid/pps45d00. (Accessed 16 Jan 2005).

116 Nichols W. Philip Morris. Project Gamma - 970000 Plans and Resources. 18 Nov 1996. Bates No. 2060532448/2450. http://legacy.library.ucsf.edu/ $\mathrm{tid} / \mathrm{jbl13e00.}$ (Accessed 16 Jan 2005).

117 Anon. Project Gamma Critical Issues \& Assumptions. 30 Jan 1998. Bates No. 2063895470/5474. http://legacy.library.ucsf.edu/tid/fog05c00. (Accessed 16 Jan 2005)

118 Heard AL. Group Tobacco Research \& Development: Visit to B\&W, Louisville: 11-14 June 1985. 25 Jun 1985. Bates No. 109869042109869049. http://bat.library.ucsf.edu//tid/eay40a99. (Accessed 20 Jan 2005).

119 Anon. Sidestream Interest at B\&W. Bates No. 600142334-600142343. http://bat.library.ucsf.edu//tid/otz60a99. (Accessed 11 Jan 2005).

120 Anon. LSS Platform Review. 1998. (est.) Bates No. 2075858561/8567 http://legacy.library.ucsf.edu/tid/zlr60c00. (Accessed 20 Jan 2005).

121 Delta Research. Project XA Less Lit End Smoke Benefit Recognition \& Acceptance Test. Feb 1993. Bates No. 514277822/8064. http:// legacy.library.ucsf.edu/tid/dge13d00. (Accessed 12 Jan 2005).

122 Holt SE, Marketing Development Dept RJR. MDD Summary Report. (MDD \#81-2477). Project CC Focus Groups (Washington, D.C., Febuary 4-6, 
1981 (810204-810206). 6 Feb 1981. Bates No. 501393472/3474. http://legacy.library.ucsf.edu/tid/fhg49d00. (Accessed 20 Jan 2005). 123 Anon. 1. Social Acceptability. 1986. (est.) Bates No. 505618007/8020. http://legacy.library.ucsf.edu/tid/thu18c00. (Accessed 20 Jan 2005).

124 Pasterczyk RC, RJ Reynolds. Marketing Research Report. Vantage Excel (Project QC) Total Proposition Test. 18 Jan 1991. Bates No. 507799338/ 9395. http://legacy.library.ucsf.edu/tid/waol 4d00. (Accessed 12 Jan 2005).

125 Anon. The Declining Menthol Market. Jul 1987. (est.) Bates No. 2048736894/6947. http://legacy.library.ucsf.edu/tid/bpc12a00. (Accessed 20 Jan 2005).

126 Bethea GG, RJ Reynolds. New Brands and Strategic Research Report. Project CC Preliminary Proposition Test. Focus Groups. Final Report. 9 May 1985 Bates No. 504588010/8021. http://legacy.library.ucsf.edu/tid/chi65d00 (Accessed 20 Jan 2005).

127 Bonhomme J, Kuhn F. Leo Burnett Co., Philip Morris. Marketing Research Department Report Merit LS in-Depth Research. 24 Apr 1986. Bates No. 2021151852/1857. http://legacy.library.ucsf.edu/tid/iar88e00. (Accessed 16 Jan 2005).

128 Hunter CS. RJR. New Business Research and Development Report. Project CC Developmental Project Test. 19 Feb 1982. Bates No. 503872103/2123. http://legacy.library.ucsfeedu/tid/gyv75d00. (Accessed 04 Jan 2005).

129 Phillips JD. Project CC. 25 Oct 1982. Bates No. 500907833/7833. http:// legacy.library.ucsf.edu/tid/lht59d00. (Accessed 04 Jan 2005).

130 Lees HJ. CC Product Development. 26 Oct 1982. Bates No. 500907834/ 7834. http://legacy.library.ucsf.edu/tid/mht59d00. (Accessed 04 Jan 2005).

131 Perfetti PF, Norman AB, Dunlap SP, et al. RJR. A Summary of Project XA Product Development. 5 Jan 1993. Bates No. 511444354/4668. http:// legacy.library.ucsf.edu/tid/fbw43d00. (Accessed 4 Jan 2005).

132 Callaham P. Philip Morris. Virginia Slims Superslims Consumer Testing. 26 Apr 1990. Bates No. 2023354750/4755. http://legacy.library.ucsf.edu/ $\mathrm{tid} / \mathrm{gka78e00}$. (Accessed 20 Jan 2005).

133 Groupe Innova Inc. Passport: Report on a Qualitative Study. 00 Sep 1984 Bates No. 400169500-400169539. http://bat.library.ucsf.edu//tid/ tnu00a99. (Accessed 20 Jan 2005).

134 BRM Research. Project PRISM Qualitative Exploration Concepts and Names Management Summary. 12 Mar 1993. Bates No. 510344910/4915 http://legacy.library.ucsf.edu/tid/uvf63d00. (Accessed 20 Jan 2005)

135 Alter S. Philip Morris. ART Marketing Strategy. 28 Sep 1987. Bates No. 2023086897/6909. http://legacy.library.ucsf.edu/tid/ujn68e00. (Accessed 20 Jan 2005).

136 McCaffrey K. Project CC Intermediate and Long Term Strategic Plan Action Standards. 19 Jan 1983. Bates No. 503717684/7685. http:// legacy.library.ucsf.edu/tid/bdr77c00. (Accessed 20 Jan 2005)

137 Anon. CC/Passport Learning. 1987. (est.) Bates No. 505934837/4850. http://legacy.library.ucsf.edu/tid/bed94d00. (Accessed 20 Jan 2005).

138 Anon. A Review and Position on XA. 1991. Bates No. 512835753/5764 http://legacy.library.ucsf.edu/tid/iqy23d00. (Accessed 12 Jan 2005).

139 Monda NR, RJ Reynolds. Product Research Report. Project XA and XB Focus Groups Final Report. 5 Sep 1990. Bates No. 509160547/0560. http:// legacy.library.ucsf.edu/tid/lwz73d00. (Accessed 20 Jan 2005).

140 Fichtenberg CM, Glantz SA. Effect of smoke-free workplaces on smoking behaviour: systematic review. BMJ 2002;325:188.

141 Farkas AJ, Gilpin EA, White MM, et al. Association between household and workplace smoking restrictions and adolescent smoking. JAMA 2000;284:717-22

142 Farkas AJ, Gilpin EA, Distefan JM, et al. The effects of household and workplace smoking restrictions on quitting behaviours. Tobacco Control 1999:8:261-5.

143 RTI International. First annual independent evaluation of New York's tobacco control program, New York State Department of Health, November 2004. http://www.health.state.ny.us/nysdoh/tobacco/reports/docs/ nytcp_eval_report_final_11-19-04pdf.

144 Department of Health and Children Ireland. Press release: Improvement in Pubs experienced by $70 \%$ of Population; 200411 August 2004. http:// www. smokefreeatwork.ie/news/detail.asp?id = 21. (Accessed 4 Jan 2005)

145 Biener L, Siegel M. Behavior intentions of the public after bans on smoking in restaurants and bars. Am J Public Health 1997:87:2042-4

146 Philip Morris. PM U.S.A. R\&D Strategic Plan 930000970000 . Oct 1992. Bates No. 2022884472/4583. http://legacy.library.ucsf.edu/tid/ zim88e00. (Accessed 17 Mar 2004).

147 Anon. British American Tobacco Co. Product Innovation in BATCo. 11 Nov 1994. Bates No. 500175812-500175830. http://bat.library.ucsf.edu// $\mathrm{tid} /$ bym20a99. (Accessed 17 Jan 2005).

148 Philip Morris USA. LSS Platform Review. 1998. Bates No. 2075858561/ 8567. http://legacy.library.ucsf.edu/tid/zlr60c00. (Accessed $26 \mathrm{Apr}$ 2005).

149 Associated Press, Wall Street Journal. "RJR's Low-Smoke Salem Pianissimo Catches Fire in Japan". 8 Sep 1997. Bates No. 2070075691/5692. http:// legacy.library.ucsf.edu/tid/aax08d00. (Accessed 26 Apr 2005).

150 Tuinstra T. Tobacco Reporter Passport to Japan; Light \& Low in Japan Japanese Smokers Prefer Cigarettes with Low Tar and Reduced Odor. Feb 1997. Bates No. $440018778 / 8780$. http://legacy.library.ucsf.edu/tid/ iiy 11 c00. (Accessed 26 Apr 2005).

151 RJR. Project VRP. 1987. Bates No. 514141251/1284. http:// legacy.library.ucsf.edu/tid/png13d00. (Accessed 12 Jan 2005).

152 Newsome JB, Dube MF, Dufour WM, Hardin BV. 0102 Social Acceptability Project CC Documentation. RDM85 64. 15 Aug 1985. Bates No. 505120678/0686. http://legacy.library.ucsf.edu/tid/ufa35d00. (Accessed 12 Jan 2005).
153 RJR. Project SPA R\&D Agenda. 1986. Bates No. 506392254/2274. http:// legacy.library.ucsf.edu/tid/dsd74d00. (Accessed 12 Jan 2005).

154 RJR. XA New Brand Vs. Line Extension. Concept Test Results. 31 Jan 1992. Bates No. 514306397/6428. http://legacy.library.ucsf.edu/tid/ yxd13d00. (Accessed 12 Jan 2005).

155 Anon. Objective: To Identify Social Acceptability Issues, Past and Current Projects That Address These Issues and the Personnel Involved in Current Projects Dealing with Social Accpetability Issues. Beta 90. 29 Jun 1989. Bates No. 509476278/6288. http://legacy.library.ucsf.edu/tid/ mmi73d00. (Accessed 12 Jan 2005).

156 R. J. Reynolds. News Release a Sensational Menthol Tobacco Which Largely Reduces Side Stream Smoke and Puts Down the Remaining Scent of Smoke Reynolds Tobacco Introduces 'Salem Pianissimo.' Sales Starts in Japan From 000801. 29 Jun 1995. Bates No. 2063875311. http:// legacy.library.ucsf.edu/tid/yji32d00. (Accessed 17 Jan 2005).

157 Wall Street Journal. "RJR'S Low-Smoke Salem Pianissimo Catches Fire in Japan". 8 Sep 1997. (est.) Bates No. 2070075691/5692. http:// legacy.library.ucsf.edu/tid/aax08d00. (Accessed 17 Jan 2005).

158 R. J. Reynolds. Japan Market Review. 11 May 1995. Bates No. 516542864/3027. http://legacy.library.ucsf.edu/tid/idd97c00. (Accessed 17 Jan 2005).

159 Anon. SIMOS. A Roadmap From Conception to Execution. 1994. (est.) Bates No. 512039602/9619. hitp://legacy.library.ucsf.edu/tid/idg43d00 (Accessed 17 Jan 2005).

160 Anon. PRISM 2. Q\&A. 1991. Bates No. 511499074/9075. http:// legacy.library.ucsf.edu/tid/fvt43d00. (Accessed 12 Jan 2005).

161 Wall Street Journal, New York Times, et al. Various Newspaper Articles Regarding Eclipse. 26 Nov 1994. Bates No. 514293893/3922. http:// legacy.library.ucsf.edu/tid/ehy90d00. (Accessed 12 Jan 2005).

162 Anon. Prism II Direct Marketing Launch Plans. Jun 1995. Bates No. 514301482/1486. http://legacy.library.ucsf.edu/tid/woz87c00. (Accessed 12 Jan 2005)

163 Tom MW. Lorillard Tobacco Company. Competitive Activity RJR Eclipse Test Market Status. 20 Nov 1997. Bates No. 82257193. http:// legacy.library.ucsf.edu/tid/brd34c00. (Accessed 12 Jan 2005).

164 R. J. Reynolds. Prism II Fact Sheet. 29 Sep 1993. Bates No. 510943860/ 3860. http://legacy.library.ucsf.edu/tid/wto53d00. (Accessed $22 \mathrm{Apr}$ 2005).

165 Bonhomme J, Bowen E. Philip Morris. Marketing Research Department Report Ambassador Campaign Product in-Depth Research. 15 Sep 1986. Bates No. 2041089158. http://legacy.library.ucsf.edu/tid/dbo05e00. (Accessed 16 Jan 2005).

166 Philip Morris. Summary of Project Laslo: Merit Ls/Lo Global Data. 14 Jul 1994. Bates No. 2057870343/0355. http://legacy.library.ucsf.edu/tid/ uum52e00. (Accessed 16 Jan 2005).

167 Heretick RP, Yatrakis GN. Activity Based Programs Merit Repositioning (Laslo). Apr 1995. (est.) Bates No. 2057756092. http:// legacy.library.ucsf.edu/tid/zwy83c00. (Accessed 16 Jan 2005).

168 Philip Morris. Outline for Low Sidestream/Low Odor Products (inferred) 1995. (est.) Bates No. 2063874147/4154. http://legacy.library.ucsf.edu/ $\mathrm{tid} / \mathrm{fzg} 05 \mathrm{c00}$. (Accessed 16 Jan 2005).

169 Reich S. Philip Morris. Topline: B\&H Thins Qualitative Research - NJ \& Atlanta. 28 Aug 1987. Bates No. 2040907625/7628. http:// legacy.library.ucsf.edu/tid/qnv96e00. (Accessed 16 Jan 2005).

170 Jannetta S, Philip Morris U. S. A. Benson and Hedges Select Thins. $18 \mathrm{Jul}$ 1988. Bates No. 681941949/1960. http://legacy.library.ucsf.edu/tid/ plp03f00. (Accessed 16 Jan 2005).

171 Bonhomme J, Eisen K, Levy C, et al. Marketing Research Department Report B\&H Thins Qualitative Research. 14 Sep 1987. Bates No. 2045038164/ 8167. http://legacy.library.ucsf.edu/tid/wss55e00. (Accessed 16 Jan 2005).

172 Bonhomme J, Paul B. Philip Morris USA. B\&H Select Thins Research. 14 Apr 1988. Bates No. 2071388405/8406. http://legacy.library.ucsf.edu/tid/ zyp32c00. (Accessed 16 Jan 2005).

173 Marketing Information Systems (inferred). BHST Ad Pack Extended Use Test. Sep 1988. (est.) Bates No. 2049338548/8697. http:// legacy.library.ucsf.edu/tid/zbel 2a00. (Accessed 16 Jan 2005).

174 Philip Morris (inferred). Analysis of Virginia Slims and Competitor Brands. 1993. (est.) Bates No. 2041570614/0669. http://legacy.library.ucsf.edu/

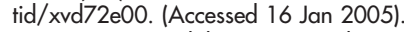

175 Leo Burnett Co. Philip Morris. Ambrosia Test Planning Session. 1988. (est.) Bates No. 2043902612/2624. http://legacy.library.ucsf.edu/tid/ ahn06e00. (Accessed 16 Jan 2005).

176 Philip Morris. Research Results On Ambrosia Concept Test. 1989. (est.) Bates No. 2021350949/0964. http://legacy.library.ucsf.edu/tid/ kzc33e00. (Accessed 16 Jan 2005).

177 Philip Morris. PM USA New Product Development Projects. Dec 1991. (est.) Bates No. 2044761367/1384. http://legacy.library.ucsf.edu/tid/ oni03e00. (Accessed 16 Jan 2005).

178 Anon. Project Stealth. Jul 1990. (est.) Bates No. 2049400355. http:// legacy.library.ucsf.edu/tid/giq75e00. (Accessed 16 Jan 2005).

179 Taylor J. Philip Morris. Project Stealth Research. 9 Aug 1990. Bates No. 2023355268. http://legacy.library.ucsf.edu/tid/aka78e00. (Accessed 16 Jan 2005).

180 Bonhomme J, Gurry N, Harper M. Leo Burnett Co., Philip Morris. Project Stealth in-Depth Research. 26 Dec 1990. Bates No. 2044124112/4114. http://legacy.library.ucsf.edu/tid/dgq03e00. (Accessed 16 Jan 2005).

181 Ellis N, Houghtonlarsen R. Leo Burnett Co., Philip Morris. Nectar in-Depths. 8 Aug 1991. Bates No. 2043913046/3049. http://legacy.library.ucsf.edu/ $\mathrm{tid} / \mathrm{iyv} 03 \mathrm{e} 00$. (Accessed 16 Jan 2005). 
182 Philip Morris (inferred). New Products Brand Review. 19 Sep 1991. Bates No. 2043982807/2850. http://legacy.library.ucsf.edu/tid/aty16e00. (Accessed 16 Jan 2005).

183 Philip Morris (inferred). Status Report - 960820. 20 Aug 1996. Bates No. 2064706876/6879. http://legacy.library.ucsf.edu/tid/qqk45d00. (Accessed 16 Jan 2005).

184 Anon. Research History Table. 25 Feb 1999. Bates No. 2073788163/ 8167. http://legacy.library.ucsf.edu/tid/bqv85c00. (Accessed 16 Jan 2005).

185 Philip Morris (inferred). Consumer and Marketing Research Summary of Results PM U.S. A. - Keswick PM K.K. - Kumagaya. Nov 1993. (est.) Bates No. 2021351890/1898. http://legacy.library.ucsf.edu/tid/hai98e00. (Accessed 16 Jan 2005).

186 Newman M. Visa Strategies. 29 Mar 1985. Bates No. 690125769/5772. http://legacy.library.ucsf.edu/tid/kbr13f00. (Accessed 16 Jan 2005).

187 Sharp R. Project Visa Creative Review. 12 Feb 1986. Bates No. 677044723/4731. http://legacy.library.ucsf.edu/tid/ftb73fo0. (Accessed 16 Jan 2005).

188 Pellett B. Visa New Pack/Copy Creative Research: Topline Results (1986124NP). 10 Oct 1986. Bates No. 679223466. http:// legacy.library.ucsf.edu/tid/ffl63fo0. (Accessed 16 Jan 2005).

189 Analytic Insight I. Capri: Creative Development -Consumer Reactions. 9 Oct 1986. Bates No. 679223467/3497. http://legacy.library.ucsf.edu/tid/ gfl63f00. (Accessed 16 Jan 2005).

190 Anon. Project Visa. 1987. (est.) Bates No. 465718074/8076. http:// legacy.library.ucsf.edu/tid/jwm01f00. (Accessed 16 Jan 2005).

191 Hacking IG. The IBPM 1988: Report and Recommendation. 15 Mar 1988 Bates No. 301767293-301767302. http://bat.library.ucsf.edu//tid/ ztt70a99. (Accessed 17 Jan 2005).

192 British American Tobacco. Project Trout: Status Report and Draft Development Proposals Management Summary. 22 Feb 1982. Bates No. 109879518-109879525. http://bat.library.ucsf.edu//tid/jxg50a99. (Accessed 17 Jan 2005).

193 Anon. Project Trout Creative Brief. 19 Mar 1985. Bates No. 301112132 301112136. http://bat.library.ucsf.edu//tid/frc3la99. (Accessed 17 Jan 2005).

194 Hirii T. Minutes of the Meeting held on Wednesday 19th February, 1986. 24 Feb 1986. Bates No. 109878245-109878249. http:// bat.library.ucsf.edu//tid/xel80a99. (Accessed 17 Jan 2005)

195 Haching I. Low Sidestream. 19 Feb 1985. Bates No. 107335070107335075. http://bat.library.ucsf.edu//tid/tsj00a99. (Accessed 17 Jan 2005).

196 Ross IA. Suomen Tupakka Oy. Note from IA Ross enclosing summary of the development work carried out for project Polka. 15 Apr 1985. Bates No. 109876608-109876613. http://bat.library.ucsf.edu//tid/bnb80a99. (Accessed 17 Jan 2005).

197 Baker RR. British-American Tobacco Company L. Novel Smoking Devices. 07 Dec 1991. Bates No. 400704255-400704258. http:// bat.library.ucsf.edu//tid/tnh50a99. (Accessed 17 Jan 2005).

198 Hook RG. Projects Greendot and Nova. 00 Oct 1994. Bates No 700217977-700217983. http://bat.library.ucsf.edu//tid/nva70a99 (Accessed 17 Jan 2005).

199 Irwin WDE. Proposal: Project LESS. 1985. Bates No. 100550334100550336. http://bat.library.ucsf.edu//tid/izb00a99. (Accessed 17 Jan 2005).

200 Anon. Project LESS (Low Sidestream Product without Sacrificing Mainstream Taste). Bates No. 401044095. http://bat.library.ucsf.edu//tid/jdh40a99. (Accessed 17 Jan 2005).
201 Anon. Tobacco Strategy Review Team: Benson \& Hedges, Review to March 1992. 1992. Bates No. 201816448-201816452. http:// bat.library.ucsf.edu//tid/diq20a99. (Accessed 17 Jan 2005).

202 Anon. Project NERO (Low Sidestream). 1994. Bates No. 500266179 500266180. http://bat.library.ucsf.edu//tid/hs190a99. (Accessed 17 Jan 2005).

203 Anon. Concept: Low Sidestream - Barclay. Bates No. 600142321600142333. http://bat.library.ucsf.edu//tid/ntz60a99. (Accessed 17 Jan 2005).

204 Anon. Product Development Brief. Bates No. 700570017-700570018. http://bat.library.ucsf.edu//tid/ogi60a99. (Accessed 17 Jan 2005).

205 Anon. Eclipse Review Meeting. 1996. Bates No. 800181842-800181848. http://bat.library.ucsf.edu//tid/wcp60a99. (Accessed 17 Jan 2005).

206 Dittrich DJ. Brown \& Williamson Tobacco Corp. Evaluation of Claremont Low Sidestream Products - Rothmans, Switzerland. 11 May 1994. Bates No. 700065577-700065586. http://bat.library.ucsf.edu//tid/nou60a99. (Accessed 17 Jan 2005).

207 Read G. British American Tobacco Company Limited. Competitor R\&D Strategies. 26 Feb 1996. Bates No. 800086187-800086198. http:// bat.library.ucsf.edu//tid/kvp60a99. (Accessed 17 Jan 2005).

208 Deaton WR. Lorillard. Focus Group Activities: Concept and Product Reduced Sidestream 100 Mm Cigarette. 17 Feb 1988. Bates No. 87091778/1785. http://legacy.library.ucsf.edu/tid/mapl le00 (Accessed 17 Jan 2005).

209 Delaura L. NSS Review. 2 Mar 1981. Bates No. 03925175/5176. http:// legacy.library.ucsf.edu/tid/hbu99d00. (Accessed 17 Jan 2005).

210 Delaura L. Lor L. NSS Focus Groups Review (Number 5546/1481). 18 May 1981. Bates No. 91502512/2513. http://legacy.library.ucsf.edu/tid/ dqu54a00. (Accessed 17 Jan 2005).

211 Cohen PS, RJR. New Business Research and Development Report. Favor Consumer Research/Store Checks. 3 Dec 1985. Bates No. 504957046/ 7053. http://legacy.library.ucsf.edu/tid/qur35d00. (Accessed 17 Jan 2005).

212 Cohen PS, RJR. New Business Research and Development Report. Favor Consumer Research/Retail Audits. 20 Jan 1986. Bates No. 504994253/ 4264. http://legacy.library.ucsf.edu/tid/ogo35d00. (Accessed 17 Jan 2005).

213 Gurry N. Philip Morris. Favor. 30 May 1986. Bates No. 2023798942/ 8944. hitp://legacy.library.ucsf.edu/tid/say25e00. (Accessed 17 Jan 2005).

214 Talmadge C. Can Smokeless Cig Rise From Ashes? 28 Jul 1986. Bates No. 950138965/8968. http://legacy.library.ucsf.edu/tid/iip54f00. (Accessed 17 Jan 2005).

215 Anon. Project Taurus: A Summary of Research. 1985. (est.) Bates No. 677312045/2073. http://legacy.library.ucsf.edu/tid/cak13f00. (Accessed 17 Jan 2005)

216 Hunter CS, RJ Reynolds. New Business Research and Development Report. MDD Topline Report. Project CC Development Groups 8. (Mdd \#81-2506). 20 Nov 1981. Bates No. 502781019/1076. http:// legacy.library.ucsf.edu/tid/uog78d00. (Accessed 20 Jan 2005).

217 McCaffrey KV. Possible Applications of Project CC to Vantage and Now. 26 Apr 1982. Bates No. 503618265/8268. http://legacy.library.ucsf.edu/ $\mathrm{tid} /$ yet85d00. (Accessed 20 Jan 2005).

218 Philip Morris. Introducing Superslims from Virginia Slims. Fat Smoke is History: Philip Morris Advertising Collection; 1990. http:// tobaccodocuments.org/ads_pm/2061003790.html. (Accessed 20 Jan 2005).

219 Philip Morris. Superslims from Virginia Slims: Philip Morris Advertising Collection; 1991. http://tobaccodocuments.org/ads_pm/ 2058502321.html. (Accessed 20 Jan 2005). 